\title{
1
}

\section{A Comfortable Home}

'Can you pass me the sauce please, Aunt Else,' asks Unn, one of the oldest grandchildren, a big seven year old girl. We are at Sunday lunch with Theodor and Carla Widerøe and their family at their house in the best district of Oslo in autumn 1943. They are all here, all who are in Norway or are not busy. So much has been happening. Little Arild, who is now five, is here for the first time. He was born the year after his uncle crashed his plane over the Oslo Fjord. Little-Rolf, two, is trying to sit nicely. He knows that he has to be on his best behaviour at his granny's and grandpa's house in Borgenveien.

It's good that the little ones are there, because this helps to preserve the rhythms of normal life. In a big family, there's always something. Nobody quite got over Arild's flying accident. Then came the war. Viggo was arrested quite early on and sent to a prison in Germany. Worse than that, Rolf the eldest son had taken up a position in Germany.

Viggo had been condemned to death, but the sentence had been commuted to ten years in prison. So far as they knew, he was still alive. They couldn't say much about that, but could only hope for the best. It was wartime, and people were being arrested. He had been betrayed by Finn Kaas, one of the worst. But what could they do? They didn't know very much, anyway, though they had managed to find out that he was now in Fuhlsbüttel Prison in Hamburg. Just think, it was now over two years since he had been arrested. They had managed to cope somehow, for the sake of the children if nothing else, and for the sake of their daughter-in-law, Solveig, with her two children aged four and six. For everyone's sake, really. 
The elderly couple missed all three of their 'boys' as they sat round the lunch table there in Borgenveien, but that was just one of the many things that had been turned upside-down. The war changed things for everybody. Two of their daughters, Edel and Else, were still in Norway, though Else's husband had had to flee to Sweden. The youngest daughter, Grethe, lived in Stockholm.

There must be some reason why Rolf had taken a job in Germany, but it was an odd thing to do. Especially as he was so talented. And to think that he was in the same town as Viggo. Yes, it's a strange world.

This particular discussion never really did take place among the extended Widerøe family; but it could have happened, with different details, when various combinations of grown-ups and grandchildren were there. Grandfather Theodor and Grandmother Carla were the gathering point. Their house in Borgenveien was the base and the focal point for a whole generation of the children of the family and their parents. Little-Rolf and Arild - for there were a Rolf and an Arild in that generation too - and Turi and Thor and Aasmund and the others can tell us a lot about that. They were always there for Christmas and birthdays, and on Sundays when they took part in family devotions before being allowed out to the garden to play. Life went on as normally as possible in what today we would call a comfortable home.

Describing the scene around the table, we didn't include Rolf's wife, Ragnhild. For some time, she was a less frequent guest at her in-laws. It was easier that way. We have built up our Sunday lunch scenario from what the generation of children saw and heard and have later told us about, recognising that they may not have fully understood at the time and that they may not remember everything from so long ago. Some of what they tell us is from what they themselves only heard about later, when they were adults. The lasting impression is of an extended family who were happy when they came together, either in 'Borgenveien' or on 'Skjæløy.'

The country property on the island of Skjæløy in the Oslo Fjord was also important to the Widerøe family. Shortly before the war, Rolf's father had sold his stamp collection and bought Skjæløy, a two and a half acre property between Hankø and Hvaler. 'There is a time for everything,' he reckoned. Now was the time above all to keep the family together. Here they held open house, with sunshine and bathing throughout one long summer. Everything was carefully recorded on Ragnhild's camera and Rolf's $16 \mathrm{~mm}$. cine-camera. Rolf's sister Else later inherited the property, with room for everybody in her house and her heart. Rolf and Ragnhild holidayed there with their own children more or less every summer, even though they lived in Switzerland, and they often had some of their children's friends there too. 


\section{At the Same Time, Somewhere Else}

That same year, there is another scene to be chronicled in the Widerøe saga. Here there are only two members, Rolf and Viggo. A German prison: Rolf in the business suit he wears at his work for the German authorities; Viggo thin, ill and in prison uniform because he had worked against the Germans. One employed by the Luftwaffe on a project developing weapons to shoot down allied planes; the other, an airman, imprisoned and condemned to death for having helped Norwegian resistance fighters to escape to England.

Their family back in Oslo round the Sunday lunch table missed them both, and didn't hear of the meeting until later.

If Theodor and Carla had been able to look into a crystal ball, they would have seen remarkable patterns of Europe's future in their family gathered round the table: a ballroom dancing teacher who married an architect from Yugoslavia; a professor of medicine; a jazz promoter and record producer who brought American stars to Europe; the Western world's first female commercial airline pilot; finance and business people; engineers, editors; more doctors; and several other occupations. In a family with six children, there were always many people round the table for family celebrations, even though there was always somebody or other missing for one reason or another. Nevertheless, Theodor and Carla would not have been entirely surprised by a vision of their family's colourful future. The Widerøes had always been pioneers following their own path.

\section{A Family of Entrepreneurs}

This was a time when the boys in the household got the best bits of meat and the girls got what was left. Carla was very ambitious for her children. Money would be spent on their education. The girls were to marry well and to be trained in sewing, languages and cooking, preferably in a finishing school in Switzerland or Germany - but they achieved more than that. Take Grethe, for example, who got her pilot's licence at the age of 17 as one of the first female pilots in Norway. Take Edel, with her skill as a telephone switchboard operator. Think of Else; when German soldiers knocked on her door to requisition her house she answered them politely in German, 'Kommen Sie bitte, herein' ('Please come in'), but added that she felt obliged to warn them that they had tuberculosis in the house and there was danger of infection. The Germans, fearing infection more than anything else in the 
world, said 'No, thank you' and left the occupants undisturbed, all of them perfectly healthy. After the war, as a single mother, she and a friend started Norway's first locum bureau service, Contact Service AS. ${ }^{1}$ The younger generations continued the business she had founded and developed it through the companies Norsk Personal, Olsten Personal Norden, Adecco and Amesto into what is today the 100 per cent family owned business Spabogruppen, a Scandinavian enterprise with about a thousand employees. Else outlived all her brothers and sisters, and was still driving a car well into her nineties ${ }^{2}$.

Arild and Viggo were pioneers of flight. Viggo was the outdoors man who roamed through the mountains with dogs and a reindeer-skin sleeping bag dreaming of becoming the new Nansen or Amundsen, until the sport of flying became his passion. Taking over his father's wine import business would have been alright, but starting his own airline would be even better. Founding an airline would be difficult enough, but in those days he would first have to explain to people what a plane could be used for in everyday life. It wasn't so long since the Wright brothers had first flown and Lindberg had flown over the Atlantic.

The other brother, Arild, had piloted airmail flights in America. Then together they established the first airmail service in Norway, between Oslo and Haugesund, and flew often in North Norway. Then followed several adventurous years of taxi flying and demonstration flights, which led to the founding of Widerøe Airlines. Over eighty years later, it is one of the oldest airlines in the World still operating.

The venture into flight took off with the legendary demonstration on 14th October 1910 at Etterstadsletta in Kristiania, as Oslo was then known. This became a gathering point for the first Norwegian flying enthusiasts. The plane was transported to the town by train. Very few people had even seen a picture of a plane at that time; now they could see a real one. 'Everybody' was there. There is no exact number, but between 10,000 and 30,000 people saw the Swedish Baron von Cederström make the first flight in Norway. History was being made in a mixture of ceremony and madness.

Theodor was there with Viggo, who was then aged six, and eight year old Rolf; Arild was too young to come. For Viggo, this was a life-changing moment. He watched wide-eyed as the mechanic swung the propeller round to start the engine and the plane took off, flew a circuit over the city centre, swung out over the ford and came back again to land 23 min later. Everybody stretched their necks up to watch and cheered loudly. The flying baron with the leather helmet was given a hero's reception and carried aloft in triumph. Viggo decided there and then that he would be a pilot. He started with model aeroplanes and aeronautical magazines from abroad, 
until he was old enough to join the Naval Air Division, where he trained as a flying officer. His dream was being realised, but it wasn't over yet.

\section{The Eldest Son Would Study}

And then there was Rolf, the eldest son, who was interested in science and who did his Ph.D. in Germany. Not many people could go abroad to study in 1920, but the Widerøe family was well-to-do and was both internationally and academically orientated. Theodor and his brothers had also had higher education, and several of them were university graduates. The family tree included doctors and theologians. Germany was the leading country in engineering at that time, and in most European countries the engineering textbooks were in German. If Germany was best that's where you went, even though it was a longer journey in those days than it is now. That's how it was in the Widerøe family.

Rolf stayed on in Germany after his course of study was complete. Many of his colleagues thought that he was German, but he didn't like that. Abroad, he was described variously as Swiss, German and Swedish, but he was really Norwegian. He was born in West Aker, which at that time lay just outside the city of Kristiania (now called Oslo). He grew up there in Vinderen and attended Halling School in Oscarsgate. He remained a Norwegian citizen throughout his 94 years. He eagerly kept his Norwegian identity, even though he lived most of his life in Switzerland.

\section{Ham and Aquavit}

Theodor, the father of the clan, was a businessman, the general agent in Scandinavia for the import of French wine and Martell cognac. He was also the wholesaler for Aalborg aquavit and Dutch vegetable oil for use in margarine production. The family of eight plus was governed firmly by Rolf's mother and lived in a villa that is owned today by Pal Waaktaar, a singer-songwriter and member of the pop group, $a-H a$. There were mother, father, three sons and three daughters. The 'plus' was for many years the children's 'Granny,' Carla's German mother. Theodor's widowed mother, whose husband had been a priest, also lived with them for a while. And then there was Aunt Polly, an unmarried friend of mother's, who also stayed with them from time to time. The six children were born between 1902 and 1915, and all grew up here: Rolf, Viggo, Edel, Arild, Else and Grethe. With piano 
playing, entertainments and a large circle of friends, and not least, exploring the woods and hills around the city.

An old-fashioned home, perhaps, but more than that. The children's friends came out and in, sometimes the basement resembled a wine-cellar, Viggo and Arild's airline colleagues stayed overnight in the attic, the airline company held board meetings and in the midst of all this the mother of the house proudly cured hams. At the same time, it was strict. You didn't go into the study without permission. And sober. The three boys shared a room until they were grown up; likewise the three girls. Granny had the fine big room with the veranda. The maids needed a room too. Everybody in the family has their own memories, but these all have a shared theme; life in the Widerøe house at Vinderen was never boring.

'Carla was more strict and Theodor was kindness itself,' one of them says.

'For me, grandfather in Borgenveien was somebody you respected. And grandmother, she was one of the best people you can imagine, she was so kind,' says another.

'She was the strict Germanic type. He was gentle,' says a third, quoting grandfather's frequent response, 'Yes dear.'

So it seems that Rolf's parents in Vinderen in Oslo were both kind and strict.

Whichever member of the family you speak to, they all talk about the hiking trips in the hills and woods around Oslo. About skis and mushrooms and resting places. When I asked Rolf's sister, Else, to tell me about their childhood, this was the first thing she spoke about. She still lived at the edge of the forest and she said that her father was an exceptional outdoorsman of the old school. Rolf too, summer and winter, whenever he had an opportunity. 'They were almost born and brought up in the Nordmarka woods and hills,' she said. 'They were quite crazy about it.' ${ }^{3}$

She went on to tell me that when her brother was home in Norway he would take her sons, the same age as his own, on hiking tours when they would sleep out in the woods. Proud of her brother, she hastened to add that he was also musical and played the piano. Took to it easily. Played a lot of Grieg. She herself both sang and played; it was part of their upbringing. She was proud of Viggo too. He played the violin, and had once played in the concert hall.

When Rolf was interviewed at the age of 90 in connection with Pedro Waloschek's book, he too started by talking about Oslomarka and his father 
and the ski tours they had done together. Father and son understood each other, as Rolf put it, and their shared interest in the great outdoors was an important part of that. An entry in his diary shows that this wasn't just boasting. On Friday 2nd November 1917, when he was 15, he wrote:

We have a day off school today. We've had a very exciting trip, Eilif, Frits, Pil, Angri, Viggo and I. We looked at the ski slope in Skaandalen and went up to Tryvandstaarnet. Then we took a very exciting route down through the woods, away from the beaten tracks. On our way we came across a beautiful little mountain lake where we had good fun.

Rolf wrote enthusiastically in his diary about such expeditions, just as he did about physics experiments. On Friday 5th October, for example:

Kaare came to see me in the afternoon to talk about a trip tomorrow. I showed him the arc light, the telephone inductor, the induction apparatus, the telegraph, the scrap transformer and all my stuff. He was amazed and interested.

The following day he reports on the outing:

Took the tram up to Holmenkolden with Kaare. Then had a three hour trip to Kolsaas. It was rather long, and my legs were tired. We had a fine view from Kolsaas. Then we went down to Stabæk and took the train home.

\section{Spent 30 Øre on Steel Wire}

That autumn he went into the first class at senior high school, known in those days as 'gymnas.' Not many teenagers commit so many formulae and notes about volts and watts to their diary. With pen and ink, he kept a log of his experiments alongside reports of broken light bulbs, poor marks, small loans and preparations for confirmation. On Sunday 7th October he wrote:

Have been to church with Dad and Herbert. Kjeld Stub spoke well, but I was not greatly moved by him. I have turned the current limiter up from 2,000 watts to over 3,300 watts. I had to write an essay this afternoon. In the evening I came across a new phenomenon. The light went out without any problem with the fuses. The current limiter had gone wrong. I got the light working again, but the fault wasn't properly solved and repaired. 
Sunday 11th November:

$\mathrm{K} \mathrm{I}_{1}=0.1 \mathrm{~V} . \mathrm{K} \mathrm{I}_{3}=0.3 \mathrm{~V}$. I had to go to church again today. Frits and Eilif came with us. Kjeld Stub preached splendidly, and I was in full agreement with him. Have found out how to make $\mathrm{N}_{2} \mathrm{H}_{4}$ and $\mathrm{HN}_{3}$.

When he spends 30 øre to buy fine steel wire for his experiments, it is recorded in his diary. Small and not so small everyday events are noted, such as the fact that the electric light experiment was successful after a little trial and error, just by putting a few pieces of soap into the water, or that:

Things went as badly as they possibly could for me in French today.

Have borrowed $1.25 \mathrm{kr}$ from B. Næss and I've bought Chemi der Kohlenstoff [The Chemistry of Carbon] 11 and $111 . \mathrm{BF}=+1.25(\mathrm{kr}) . \mathrm{K} \mathrm{I}_{1}=0.2 \mathrm{~V}$. $\mathrm{K} \mathrm{I}_{3}=0.85 \mathrm{~V}$. It's still raining.

Problems with the fuses are a recurrent theme, for which he often blames his clumsy-fisted brothers. Big brother Rolf is trying to be responsible. His main concern is to maintain the power supply to Granny's room. But on Monday 8th October it happens again:

This morning the current limiter went crazy again. We had no power at all until I was able to get it sorted. In the afternoon it went on bouncing up and down all the time. We had about 2,600 and everybody was complaining loudly. When I went up to have a look I found that several parts of the current limiter had melted in a nasty spark formation. The current limiter is now running between 3,000 and 4,000.

The language in the diary is direct and to the point. Not very elegant, stylistically rather chaotic. But if writing a diary at the age of 15 is about putting onto paper the contents of the day and your head and your heart, it gets full marks for content. And for fine writing. There is nothing to suggest that it has been locked away and kept secret. It is just an ordinary, lined notebook. He obviously confesses to his diary. The notebook is of the type he used all his life to make sketches and notes. His name and the from-and to-dates are on the front page, but there is no extra warning note such as 'NB! Strictly private.' His eldest son gave me the diary with a simple 'There you are,' together with other written material his father had left. So let us assume and hope that the writer would have thought it good that now, so 
many years later, we can share his confidences in between the formulae, such as when he was philosophical and in love on Thursday 18th October 1917:

This morning $\mathrm{K} \mathrm{I}_{1}=1 \mathrm{~V}$ Now at mid-day $\mathrm{K} \mathrm{I}_{1}$ is swinging between $1 \frac{1 / 2}{2}$ and $2 \mathrm{~V}$. In the afternoon as I was walking back from the orthopaedic clinic I saw Elsie coming down Hegdehaugsveien. I greeted her and she responded and just her glance, her eyes, were enough to make me incurably in love with her. The human being, that is I, am a remarkably complicated person, when I am free from that sort of thing I think it over as if I was unassailable. 5 min later a single glance from Elsie is enough to drive me crazy. $\mathrm{K} \mathrm{I}_{1}$ is oscillating steadily between $1 \frac{1}{2}$ and $2 \mathrm{~V}$. K.F $=3.20 \mathrm{kr} \mathrm{BF}=0.60 \mathrm{kr}$.

\section{King Oscar II Comes to Visit}

Rolf knew a lot about his family and spoke about his family background in several interviews. His paternal grandfather was a priest, who was born in Frosta in Trøndelag and died of stomach cancer 'in Kongsvinger as provost and parish priest in Vinger on 20th August 1891 at 10.30 in the evening, after being ill for 24 hours.' Such is the entry in the family history, copied from old official records. ${ }^{4}$ Before he came to Kongsvinger he had been a priest in Trøndelag, where according to the local archives people said that 'Widerøe was a real man of the people' and that 'he knew more than just being able to recite the Lord's Prayer.' There was 'something strong and bold about him, like Peder Dass,' and 'The old people still remember him as the best priest the parish had ever had.' ${ }^{5} \mathrm{He}$ and Edel 'celebrated their silver wedding on 18th January 1883' and (in brackets) 'Great ceremony with presentations, speeches, and so on.'

King Oscar 11 and Queen Sofie were frequent visitors to the Widerøe grandparents in the rectory at Kongsvinger, where there was a special room known as 'the king's room'. Of the Swedish union kings, Oscar 11 was the one who spent most time in Norway, and Kongsvinger was a convenient stopping place on the route between Stockholm and Oslo. Also, the queen was in poor health and liked to spend time in Norway convalescing, preferably with the Widerøe family.

Grandmother was given a bracelet with green jewels by the king, engraved 'To Edel Widerøe from Oscar Il' and the date. It was inherited by Rolf's sister who was also called Edel and who as a child had spent a lot of time with her grandmother. Grandfather, the parish priest, had been long dead 
before Rolf and Edel and Else and the others were born, but they had close contact with their grandmother, Edel Johanne Solem. Her family roots were from the big farm of Solem in Klæbu, south of Trondheim. The farm had belonged to the family since the 17th century, and Edel's sister was married to General Fleischer, famous for his part in the Battle of Narvik during World War ll. Rolf's grandmother did well in bringing up her nine sons and one daughter. She was a widow for almost 37 years and eventually moved to live with her son Theodor in Oslo, where she died in summer 1928, having lived long enough to know that her grandson Rolf had got his doctorate. Her son Sofus had long since qualified as Doctor of Medicine and specialised in surgery. He served as an army doctor in Serbia, but he was in Arild's plane when it crashed and he didn't survive. Another of Edel's sons had become a priest like his father, and another was an accountant who later had Widerøe Airlines as one of his clients.

\section{The Wealthy Family from Romsdal}

Going back to the 16th century, the founder of the Widerøe family was Aage Hanssøn from Romsdal. He was married to Synnøve Oudensdatter from the Aspen family, who can be traced right back to the 14th century and who were originally from Brandenburg in what is now Germany. The family owned farms throughout the land. Looking at the family tree and its connections, we find high status names such as Gyldenløve and Rosenkrands and people who consulted with the archbishop and kept company with the aristocracy and Lady Inger of Østråt and Vincent Lunge's bailiff. We find knights and national politicians and others with fine historical titles, governors, regents, chancellors and squires. Back in the 15th century, the family tree included 'the biggest landowner who had lived in Norway up to that time,' with over 1,000 farms. There are also estates and goods acquired from the cathedral in Trondheim, houses referred to as 'The King's House' or 'The Manor;' indeed all the possessions appropriate to a venerable, wealthy dynasty. The founder of the family lived on Veøy, an island west of Molde which is mentioned by Snorre Sturlason; the place where Håkon Herdebrei was killed in the Battle of Sekken against Erling Skakke in 1162. Until the late 16th century Veøy was the biggest trading centre in the district, while Molde was just a little coastal settlement. The island was situated at a nodal point for boat traffic in Viking times. Veøy is also known as 'The Holy Island,' and may have been a cult centre and the site of a pagan temple in heathen times. ${ }^{6}$ 
The founding father's son, Ouden, was the first to use the name Widerøe. In the first hundreds of years the name was written in many different ways, such as Veeyir, Vidøy, Vedøy, Widø, Widøy. Various explanations have been offered, but one is that the name originates from the name of the island, as it was usual in those days to adopt the place name as the family name. Several succeeding generations on Veøy were trendsetters both in wealth and in power, but for one reason or another the place lost its influence, possibly in connection with the death of Archbishop Engelbrektsøn. The Widerøe clan then moved to Lyngvær, a fishing and trading centre, but this also became too small and they moved on to Molde. There they took part in developing the settlement into a town at the beginning of the 17 th century. If we trace the tree upwards to Rolf's branch of the family in the 19th century, we find many senior public officials and businessmen.

\section{Hiding Grandpa in the Oven}

Rolf's mother, Carla Launer, had a no less colourful family history. Her parents were both German but had moved to Norway before she was born. Her father, Carl Gottlieb Launer, was born in 1819 in DüroBrockstadt, south of Breslau. The name Launer originates from the Huguenots who fled from France during the reign of Frederick the Great. Carl Launer's dream in life was to be a master brewer. So he travelled on foot all the way to Constantinople as a journeyman gathering knowledge and experience. At that time, this was the way to become trained as a qualified master brewer, and membership of the Guild of Brewers was much sought after. From Constantinople he travelled to Vienna, where he became involved in the Uprising of 1848. He took part on the side of the revolutionaries and became a captain. He was wounded. His then wife hid him in the bakery oven to avoid capture and cared for him until he recovered. But then she died and he resumed his travels, still with the dream of becoming a master brewer.

He ended up in Northeim, near Hanover. Here he married Johanne Dorthea Margrethe Cramer, who was fifteen years younger than him. The pair of them moved to Halden in Norway, where he was able to realise his dream and become a master tradesman, having been headhunted to teach Norwegians how to brew beer. Rolf's mother Carla was born in Halden in 1875, but the family later moved back to Germany, where Carl got a job as a master brewer in Hamburg. In later life they moved back to Halden where he died in 1902, the year his first grandson, Rolf, was born. 
His widow, Johanne, lived her final years with her daughter and son-inlaw in Oslo, in the house where Rolf and his siblings grew up. She died in 1925. Her daughter Carla, Rolf's mother, was a strong and ambitious lady who died in 1971 at the age of 91. 'I may have inherited something from my grandfather, possibly including the urge to travel, ${ }^{7}$ Rolf said when he spoke about his mother's side of the family.

Jørgen Holmboe (nephew; Ragnhild's sister Anna Margarete's son) 'You can safely say that the Widerøes have been more than just an ordinary family in Norwegian society.'

Arild Widerøe (eldest son) 'We were in no doubt that Dad was something special.'

Thor Spandow (nephew; Rolf's sister Else's son) 'We were brought up to be frugal. I grew up in my grandparents' house at Vinderen, lived there with my mother from the age of three until I was twenty. Granny was strict, we weren't allowed to have friends home in the evening to dinner. But when Granny had gone to bed, Mother said "Come and eat" to everybody.'

Thor Spandow (nephew; Rolf's sister Else's son) 'Life was strict at Vinderen, especially when Uncle Viggo came to visit. At dinner the rule was that children should be seen, not heard. There was steak every Sunday, herring or fish on Monday, and porridge or pancakes on Saturday. On Sundays in winter, the dining room was warmed up and we ate there. After dinner the grown-ups went into the smoking room and the children were not allowed there.'

Aasmund Berner (nephew; Rolf's sister Grethe's son) 'They were out in the woods and hills a lot. Uncle Viggo, for example, the first thing he did when he came home after four years in prison and looked like a corpse, was that he gathered his friends together and they went out on an overnight trip. He preferred to sleep in a tent in the woods and watch the birds, instead of being at home with his family. His friends seemed to come first.'

Rolf Widerøe jnr. (youngest son) 'I remember when some German soldiers passed through the back garden of our house in Roa. I remember it well, because we had a garden that led into a wood and below that there was a football pitch. And there they were, between the wood and our garden. And ever since I was a child I've always thought that there was something sinister about people wearing military uniforms.'

Arild Widerøe (eldest son) 'I remember when we sowed potatoes in our big lawn. Two people walked ahead pulling the plough and one walked behind to steer it. It was a big event. All the neighbours stood watching and laughed and 
found it funny, even though it was - no it wasn't sad - but it was a serious situation, for potatoes were important at that time. And I remember my mother going down into the town to exchange things. That must have been on the black market. And I remember once when we were in town there was a fire alarm and we had to sit for two hours in the underground, on the Røatrikken that went up from The National Theatre. And we weren't allowed to parade with the Norwegian flag on 17th May. When peace came, I remember the German transports of people freed from the prison at Grini, coming down along Vekerøveien, and people stood watching and were happy.'

Aasmund Berner (nephew; Rolf's sister Grethe's son) The aircrews used to stay over in our flat in Stockholm, and they were often babysitters for us children. Uncle Viggo's wife lived in Voksenlia, and the planes sometimes flew low over her house and dipped their wings in salute. Sometimes they were chased by fighter planes. Once they came over Hamar and Saksumdal, and I know that one of the pilots - I think his name was Piltingsrud - was being chased by a fighter, so he dived down towards the ground and levelled up just in time but the German fighter didn't make it and crashed into the ground. And then he went on to Scotland. So he was able to give us news, because he had heard from somebody in Stockholm that Uncle Viggo was still alive in Germany.'

Egil Reksten (brother-in-law) and Louise Reksten (sister-in-law; Ragnhild's sister Louise):

Egil: Yes, there were several Widerøes. We knew Viggo too.

Louise: He was a very fine type too.

Egil: Yes, a good fellow.

Louise: Yes, a really good sort.

We can safely say that Rolf's family background was solid and exciting, on both sides of the family. At the time, however, the friends with whom he grew up were reckoned to be more important than the family. A friend whose father subscribed to Science Illustrated, for example, opened many possibilities. Rolf was rather alone in the family in his interest in natural science, but when visiting a friend who later became a professor of geography, he could read the magazine, Naturens verden ('The World of Nature').

Else, his sister, said that they were often scared he would blow the house up with his experiments. Her other brothers, she says, were only interested in planes. The boys shared a room, and as Rolf wouldn't tolerate anyone interfering with his circuits and causing complications, there was a certain amount of pushing and shoving. Rolf would push his equipment so far as possible under 
the bed, which obviously just excited his little brothers' curiosity. Else feared that her big brother thought she was a little stupid, and she still remembers with slight anxiety that he called her 'fathead' once when he had to help her with her maths. There is no doubt that he was especially talented, she said. She also understood clearly that he was stubborn and knew exactly what he wanted.

A high point in his boyhood career in physics was when he led a telegraph cable over to the neighbouring house at the age of 14 or 15 , so that he could communicate with his friend using Morse code. The equipment in his room, a mixture of electrical and mechanical, was an important part of his teenage years as for many other boys at that time. But in Rolf's case, the fascination continued. Getting things to work and at the same time understanding the theory behind them became an obsession. The order of priority could vary. In adult life, his research was both a driving force which led to practical applications and a necessary response when things didn't work. How lucky he was to be a teenager just at that time in history, the decade when atoms were 'discovered.'

\section{King Solomon's Mines}

Rolf considered himself to be a fairly ordinary high school student. His school reports show that he did best in science subjects, but it is difficult to say how much that is related to a lack of interest in other subjects. Anyway, he did buy extra books on physics, chemistry and mathematics. His urge to learn led him to find stimulation and knowledge without the facilities available to us today through the Internet and social media. His maths teacher was an important role model, and Rolf joined the Norwegian Mathematical Association as a teenager because of him.

He got insight into higher mathematics through a series of booklets, Sammlung Göschen, issued by the German publisher G. J. Göschen. On one occasion he sent a question to a professor of physics at the university and got an encouraging letter back with a list of books that could give him the answer to what he was wondering about, concerning Planck's Quantum Theory and Einstein's Theory of Relativity and other topical themes. These might be thought to be too 'grown up' for him, but as he himself said, 'My physics teacher knew nothing about this, so I had to explain it to him,' and he did give a lecture on Einstein at school when he was 17.

His diary shows that books were a major item of expenditure. On Tuesday 9th October 1917 he wrote:

Today I have bought Qualitative Analysis from B. Næss for $1.8 \mathrm{kr}$. I paid 60 øre from the book fund and he had borrowed 20 øre from me. The rest was 
paid for together with an ampere and volt meter I had bought from him. There was still $5 \mathrm{kr}$. and I got Dad to take that out of the bank for me. Have got $50 \varnothing$ re for some electrical goods. B.F $=28 ø$ re K.F $=2.88$ kroner.

But there are also entries such as: 'Got a book from Dad.' He was no ordinary scholar, but he wasn't a nerd either. 'Went to the cinema and saw "Civilisation." It was altogether magnificent,' reads the diary entry for Friday 26th October 1917. He got his dose of fiction and action stories, in fair measure. There was no Harry Potter, but they had Jonas Fjeld, the Norwegian answer to Indiana Jones the doctor, explorer and adventurer who fought with bandits and faced mortal dangers in distant latitudes. An over-confident hero full of the joys of life, created by Øvre Richter Frich to go out into the world with his inventor friend and achieve the most sensational coups; a major criminal who is saved at the last moment by fate taking a hand in events and facing him with challenges that enable him to find love and be reconciled with society. The first book in the popular thriller series came out when Rolf was nine, and he felt as if it had been written specially for him.

Then there was Sir Arthur Conan Doyle, the author of the Sherlock Holmes stories, with his book The Lost World, about a plateau in the Amazon forest still inhabited by dinosaurs. At least, that is the genial and eccentric Professor Challenger's hypothesis. His views are scorned by the scientific community, but he sticks to his hypothesis and a scientific expedition of four men goes out into the unknown to investigate. This is obviously a more daring, more dangerous and more fantastic journey back in time than anybody could imagine. Another favourite-even though it was not newwas Rider Haggard's adventure novel about King Solomon's diamond mines. According to the story, an enormous treasure lay hidden in King Solomon's mines deep in darkest Africa, well protected by an aged witch, Gagool. There was a curse over the place. Many had tried to reach it but none had come back alive.

As a young boy, Rolf devoured books such as these and all the serial stories he came across in pamphlets and magazines. In later life he enjoyed science fiction and futuristic novels.

\section{Into the Atomic Age}

He also read newspapers. That was how he learned about the achievement of Rutherford, the physicist who had managed to unveil the structure of the atom, thereby initiating the atomic age. The theory about electrons orbiting 
round the atomic nucleus, the understanding of the structure of the atom and the development of quantum mechanics were still in the early stages of development, but the splitting of the atom fascinated him and ignited his life-long interest. At the age of 79 when he was giving a lecture about his role in the development of sub-atomic physics, Rolf started by saying that when he was in his teens it was Rutherford's discovery that had sparked his lifelong interest. ${ }^{8}$ As further historic discoveries were made, he heard and learned about them and became part of the development. Several years previously, in his only formal interview with the newspaper, Aftenposten, he had said that the main reason he had become interested in high-energy accelerators in his younger days had been because of the great possibilities he saw in them for atomic research. He described Rutherford as very far-sighted, but as a practical man he thought that not even Rutherford had fully anticipated the possibility of practical applications arising from the splitting of the atom:

The developments have shown that he was mistaken. So far as the accelerators are concerned, I think that the treatment of cancer with high energy particles and radiation must be considered a very useful by-product. ${ }^{9}$

For a long time, people had believed that the atom was the smallest entity that existed. Then we understood that we could split the atomic nucleus into protons and neutrons, and these were thought to be the smallest building blocks. We now know that even they can be broken into component

parts. Rutherford's point was that if one bombarded the atomic nucleus with radiation of high enough energy, one could learn even more about the structure and properties of the atom. This was the foundation of a new branch of physics, namely experimental nuclear physics. It was a question of finding a way to produce high-energy particles, and this was what came to be the major part of Rolf's work, creating accelerators that could create such high-energy radiation. That takes us into the realm of high-voltage electricity.

\section{Electrical Engineering}

After passing the university entrance examination in 1920, Rolf was in no doubt what he wanted to study. It had to be electrical engineering, and it had to be about high voltage and large power applications. If he was to make anything of his career he would need to become a graduate engineer, and his parents were quite clear that to achieve this, he would need to go abroad. 
Norway had just established a technical college in Trondheim, but father reckoned that a college with 100 students would be less stimulating than the traditional institutions on the continent.

Rolf celebrated his 18th birthday that summer, and when the semester began that autumn his father followed him to Germany. He was to matriculate into Die Technische Hochschule in Karlsruhe in South-west Germany, near the French border. He soon found his feet. There is not a word of homesickness anywhere, even though he was leaving his friends, his five brothers and sisters, his mother and father and two grandmothers. The young student from Norway flourished. Life was really starting now. The environment was congenial, and even though he thought that 3,000 to 4,000 students were rather many, he considered that the relationship between students and teachers was friendly and informal. He remembered the names of his teachers for the rest of his life:

I especially remember Professor Schleiermacher in theoretical electrical engineering; a lovely old man. We also had a good professor of mathematics, he was called Böhm. In physics we had Professor Wolfgang Gaede, he was one of the 'gods,' rather high above us students. ${ }^{10}$

He was still working with transformers, resistors and condensers, and now there were also lectures and lab work, group work and set projects, which all came together to consolidate in his mind the theories behind his childhood electrical endeavours. The guru of electrical engineering, Professor Richter, was one of the reasons Rolf had chosen the college in Karlsruhe. Rolf was fascinated by Professor Richter's very practical lectures. The syllabus included work experience, which in Rolf's case consisted of a month's practical work in a motor factory in Strasbourg. Here he had to build an electric motor, including making the windings; not an easy task. Climbing masts and mounting cables were also part of the course.

Enthused and energetic, Rolf also threw himself into projects outwith his technical syllabus. One of the first of these was when he wrote an article with the serious-sounding title Analysis of Inflation and submitted it to the academic journal of the Norwegian Economics Society in Oslo. This was at the time when the German mark was very low and it was said that one needed a wheelbarrow full of money to buy a loaf of bread. His father had provided him with money, and Rolf was following the exchange rate closely. In his usual methodical way, he started plotting the rate on a chart, with the rate on one axis and time on the other. He used the American dollar as the basis of comparison, and plotted a dollar curve that went from the floor 
to the ceiling on the big sheet of paper fastened to the wall of his room. At first the dollar rose in a more or less straight line, apart from a few swings. In January 1922 a dollar was worth 192 deutschmarks, but by December it had reached an incredible 4,200,000,000,000 marks and the exchange rate rose so steeply that he had to continue the chart onto an even bigger sheet of paper. Everybody was worried about the economy, not just students living on money from home. Rolf's article was accepted, and was published in the journal in 1924, on pages 189 to 206. Rolf had not formally studied economics, but he had an enormous appetite for life, with corresponding talent and enterprise.

\section{Student Social Life}

Much of the student social life in Karlsruhe took place in The Nordic Club. Most of the members were Norwegians and Swedes, with a few Finns, an Icelander and a Dane. Rolf described it thus:

We partied a lot. There were regular national festivals to be celebrated, with cognac and lots of Swedish punch.

As aspiring engineers, their main preoccupation was to find solutions to everyday practical problems. This involved making inventions and having them patented. Their creativities followed many diverse routes. Rolf spoke about some of them, such as the chemistry student Erik Rotheim who invented the aerosol spray can during his time there and managed to have it patented but died before he could experience its success. There were others, too:

I also remember Jack Nielsen, who had been Norwegian Tennis Champion. He became master brewer at Ringnes, and I bought his bicycle when he left for home. Grude from Stavanger was a great baritone singer. There was an architectural student called Bjørnson-Langen. His mother was a daughter of Bjørnstjerne Bjørnson. I remember he was quite entertaining. And then there was my good friend Kaare Backer. ${ }^{11}$

Backer became a structural engineer and founded the contracting firm Dipl. ing. Kaare Backer AS. They kept in contact throughout their lives, and Rolf took part in Kaare's diamond wedding celebrations when they were both about 90 . 
Rolf often came home during the holidays, or had visitors from home. Judging by all the mountain-tops in the family photograph albums, there were many ski and hill-walking trips. On all types of high days and holidays. With fellow-students and family members. The brothers together, all three of them or sometimes just with Viggo. Former schoolmates too, either visiting him abroad or getting together when he was home in Norway. Sometimes brothers and friends together, often with his own and his friends' parents, and uncles and aunts and old neighbours. Logged on the stiff, black pages of the photo albums: Biong's Cabin Easter 1921; GarmischPartenkirchen and Nürnberg Pentecost 1921; Feldberg Christmas 1920-21; Schattwald Christmas 1922-23; Easter trip Odenwald 1926; trip with Viggo summer 1926; Feldberg on ski Christmas 1926-27; Wangen's Cabin in Eiker winter 1927-28 — moonlight trip; Longvass Cabin 1928.

If they weren't on skis, there were towns and car tours: Brussels summer 1924; Paris Pentecost 1924; Viggo visiting in Karlsrube autumn 1922; 'Kaaresbo' August 1925; Rukkedalen autumn 1923; Fougner's Cabin Kolsas 1921; tour in mother's and father's first car autumn 1921; long car tour summer 1922. His childhood home in Vinderen not only had antique Biedermeier furniture and a smoking room. They were also among the first people to get a car, an American-made 'King.' Like most other cars at that time it was black. The family bought it about the time Rolf was beginning his studies. Father owned it, but never drove it. Viggo and Rolf were the chauffeurs, and it was mostly used for family tours or to take business contacts on an excursion. In a country that according to the national records office had 6,700 cars in 1920, an offer of a trip in a car was something to be valued.

\section{An Idea on the Side ...}

While pursuing his studies, Rolf was also incubating an idea. Behind this lay Rutherford's theories about how one could create high-energy beams. By the age of 20, Rolf was already wondering whether the same principle that was applied in an ordinary electrical transformer to change an electrical current from one voltage to another could also be used to accelerate electrons. He envisaged a transformer with the secondary winding removed and a glass tube in the shape of a slightly flattened doughnut put in its place. Could this be used to accelerate particles in the same way as could be done using very high voltages? Such high voltages would be dangerous, and there was no practical way of generating them. So the world needed his invention. 
He had developed his idea thus far when he was in the fifth semester of his college course in autumn 1922, but there was much groundwork still to be done. One of the questions was whether electrons in a circular glass tube would behave in the same way as they would in a copper cable in a normal transformer. He thought it was possible to achieve this, but that as the electrons were not restricted within a copper cable he would need to use a magnetic field to keep them on track.

He was unable to solve this problem meantime, but he had written all his ideas down in a notebook with a blank, black cover bearing the title 'Technical Ideas.' On 5th March 1923 he wrote: 'The radiation transformer was conceived to create sufficiently concentrated energy to split the atomic nucleus. Four years ago I wanted to achieve this by ...,' and there follows a technical explanation. Then he had realised that he might be able to do it a little differently, and he gave a little explanation of that.

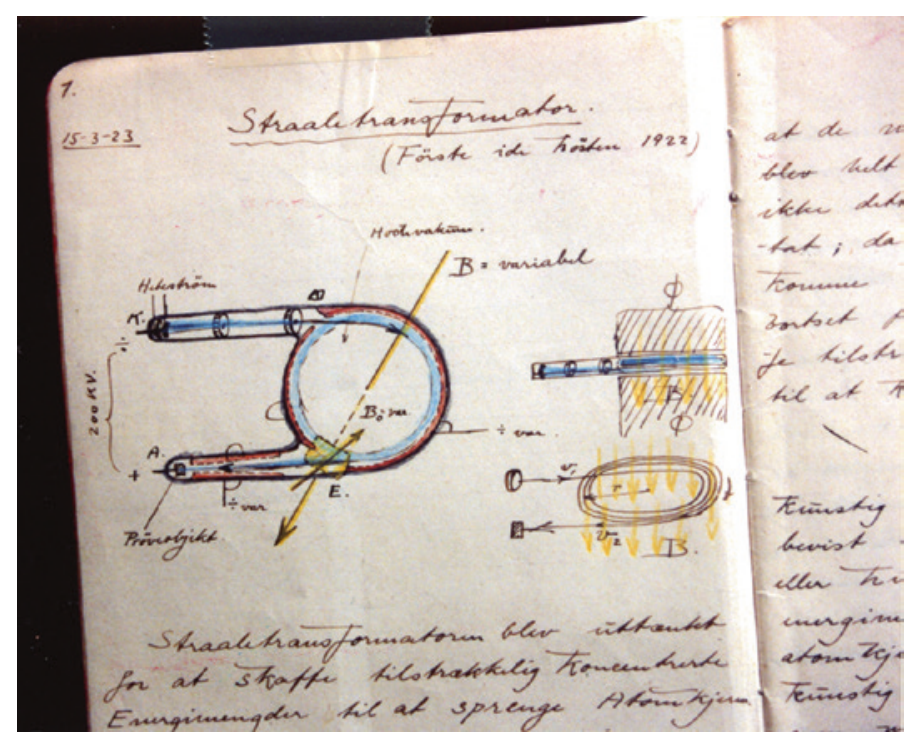

As a twenty year old student in Karlsruhe, Rolf Widerøe drew this sketch of his idea for a betatron. His notebooks of the betatron are in ETH Library in Zurich. (Photo Pedro Waloschek) 


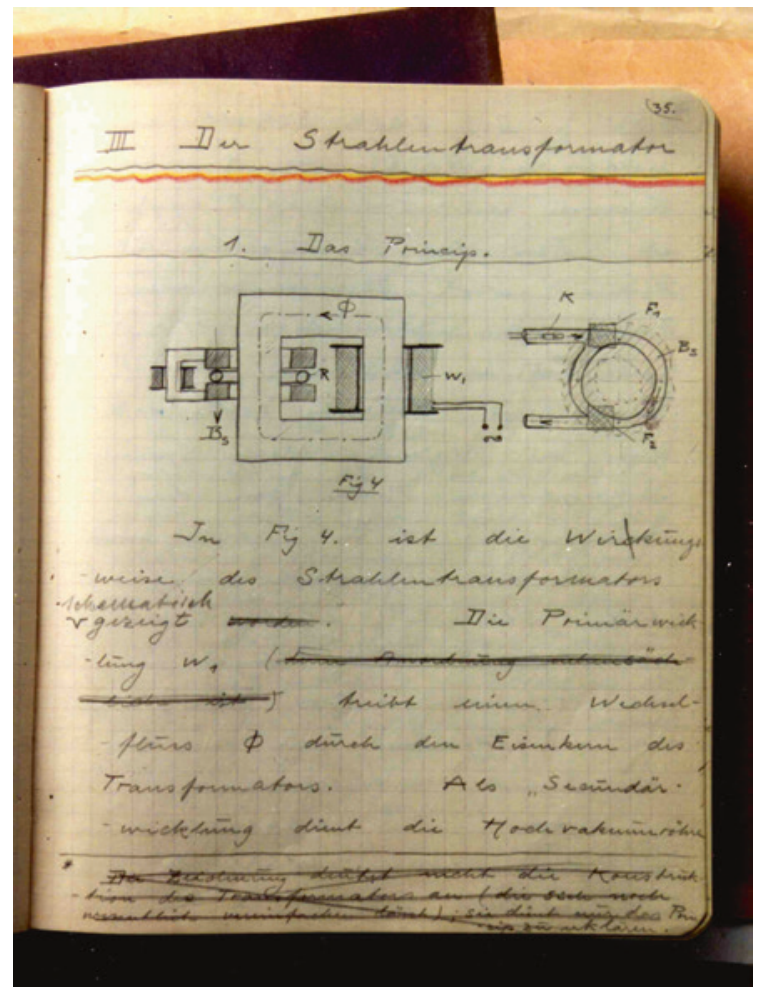

A further sketch by Rolf Widerøe, which explains more precisely the operation of the betatron. (Photo Pedro Waloschek)

\section{... Set Aside for Now}

But he had to sit exams too. That was why he was there, to study for the degree that today would be called 'Master of Technology' or 'Master of Science.' The invention-or idea for an invention-that he was developing on the side had to be set aside for the time being. He continued to write down his ideas, sometimes in German and sometimes in Norwegian, alongside calculations and sketches in his notebooks. These little notebooks are a representation of his life and his thoughts, and he kept them for his whole life. Pictures of pages from his notebooks can now be found on the Internet, in textbooks and in physics lectures the world over whenever his theories are being explained. 
For the time being, however, he was still a student. Before putting the idea aside, he was so bold as to submit his design to a patent office and apply for a patent. He never got a reply from them. Many years later when he was back in Karlsruhe he found that the whole area where the patent office had been was completely changed, and he never did discover what had happened to his first patent application.

Just now, he had to concentrate on his undergraduate dissertation. For this, he chose a very practical topic, typical for a high-voltage electrical engineer. Knowledge should be applied to something useful. There was a wave of electrification sweeping across Europe, including Norway. Power stations were being built and networks of high-tension cables were being strung up on masts across the land. So high-tension was to be his field. He would master areas such as electromagnetism and transformer technology. The teacher of high-tension technology had written a book on the subject, but Rolf thought that one of the calculations in the book was wrong and he corrected it in his own dissertation. First he worked it out mathematically, but then he asked for a deferment so that he could investigate it experimentally. He persuaded the college to provide equipment and a workshop, where he built a model of a high-tension mast on a scale of 1:100. He put the mast in a bath of electrolyte solution, so that he could measure the change of voltage in the fluid. His critique of the teacher's mathematical problem was accepted and his dissertation was given a grade of 5.9: the maximum was 6 .

When his dissertation was complete and the exam was over, he returned home to Oslo in 1924, initially for his six months of practical experience. This consisted of maintenance and development work in the railway workshop. Then military service in summer 1925 , which he summed up in two sentences:

For 172 days I was in command of six men and a farmer with a horse and cart. It was a fantastic summer! ${ }^{12}$

His next goal was a doctorate. His interest in electronics had grown during his studies, and to be an electrical engineer was not enough for him. The idea of getting electrons to go round in a circle still fascinated him, but if he were to realise his dream he would first need to know more about the theory. After a year at home he moved back to Germany. 'I believe in my ideas. Karlsruhe, here I come!'

In Karlsruhe he went to see his former lecturers. Said he would like to be taken on as a doctorate student. And for his doctorate thesis he would like to build a new type of accelerator, an induction accelerator or 'radiation 
transformer' as he called it at first. A machine the world had not seen the like of before, that could be used whenever there was a need for high energy. World-changing! 23 years old! We could say that this was a little more than normal youthful enthusiasm and ambition. Did he see any obstacles? Or just the goal? Starry-eyed? Or brilliant? Either way, it was worth a try.

\section{'It Won't Work!'}

His favourite professor, Schleiermacher, received him warmly and read carefully through the notes and calculations he had brought with him. 'Yes, this should work out. You've got the topic for your thesis here! Just get going!' ${ }^{13}$ But the teacher of electrical engineering theory didn't make all the decisions and Rolf had to go to Gaede, the venerable professor of physics. Gaede was not so impressed. He could certainly accept Rolf as a doctorate student, but he was very doubtful about the idea of a radiation transformer. It wouldn't work. Rolf could get to choose a different topic. There was no way the college could accept that constructing and testing a transformer according to the ideas proposed could be accepted as a doctoral thesis. It was technologically quite unrealistic, even if he did manage to create the best vacuum in a glass tube that was possible at that time. There would be so many gas molecules still present that the electrons, instead of travelling several thousand kilometres in the round glass tube, would be absorbed too quickly, much faster than they could be accelerated. But as the professor said, he would be welcome to study further in his old college-on a different theme.

It must have been a personal victory for Rolf thirty years later when the college in Karlsruhe bought one of his betatrons to use in physics experiments. The old professors were not there any more, but nevertheless.

The newly qualified engineer had not allowed himself to be beaten. He knew how to solve the problem of disappearing electrons, and he did further calculations that he thought showed that Gaede was wrong. However, he didn't go back. He decided that Karlsruhe was no longer the right place for him. He was determined to build a radiation transformer. If he couldn't do it here, he would do it somewhere else, and what's more when he thought it over carefully he concluded that the technical facilities in Karlsruhe were not good enough for his plans. Basically, he had grown out of the whole milieu of Karlsruhe. Whatever the obstacles he faced, lack of self-confidence was not one of them. Difficulties are just challenges to be overcome, with back straight and head held high. 
So he sat down and wrote a letter to another technical university, in the city of Aachen much further north in Germany, level with Bonn near the Belgian border. He knew that in Die Rheinisch-Westfälische Technische Hochschule in Aachen there was a professor called Walter Rogowski, and he addressed the letter to him. He came straight to the point and asked if he could go there to do his doctoral thesis. He had found Rogowski's name in the journal Archiv für Elektrotechnik where Rogowski and another researcher had described an attempt they had made. The journal was published by Springer, the world-renowned publishing house which already at that time was almost a hundred years old. The journal continues today under the name, Electrical Engineering.

The journal and its editor would weave in and out of Rolf's life for the next twenty years, and it is interesting to speculate whether he would have done the same if he had known what would happen later. But Rolf and the professor were on the same wavelength, and Rolf has given an enthusiastic account of their first meeting and how it came about:

Rogowski wrote back immediately to say that was fine. Obviously I could work with him; no problem. He was due to be going to Switzerland on holiday between such and such dates and would be coming through Karlsruhe on the way back. "Meet me on the train, then we can travel together to Mannheim and you can tell me all about it." So I did as requested. The train journey took an hour. I don't think he really understood many of my explanations, but I mentioned several times that I planned to build a transformer of six million volts and that must have really caught his imagination. He was ambitious and wanted to be a little ahead of the competition. "It sounds good. Come to Aachen and we can sort out the details." ${ }^{14}$

The road was clear, and the evening before he left his old student flat in Karlsruhe he had a wild farewell party:

We ended by hanging all the chairs up on the wall. I got onto the train in the middle of the night, or early in the morning. The cleaner was angry when she saw the state of my room, but my friends dealt with that.

In Professor Rogowski he had found someone brave enough to let him prove himself. Another benefit of being in Aachen, considering the specially manufactured glass tubes he would require, was that there was a good glass-blowing workshop there. 
He started his work in May 1926. The college in Aachen was considered slightly unconventional, which suited him well. It was a stimulating environment. Here Rolf met, among others, the man who had been Rogowski's co-author of the article that had led him to apply to Aachen. ${ }^{15}$ But above all he met Ernst Sommerfeld who was the son of the famous physicist Arnold Sommerfeld. Ernst specialised in patent registration and over the years he would come to handle most of Rolf's over 200 patent applications. The two of them became close friends and went hillwalking together, and Ernst visited Rolf in Norway several times.

Rolf enjoyed Rogowski's lectures on electrical engineering, and up to a point he enjoyed being taught by the professor of aerodynamics, though he obviously found it more entertaining to play tennis with his laboratory assistants than to listen to the professor himself. ${ }^{16}$ The biggest department in the college was metallurgy, naturally enough, as it was situated in a mining and industrial area. There was nobody in his own department working in the same field as he was, and moreover he was the only Norwegian. So he had to manage the project mostly on his own, as there were few people around with relevant knowledge to help him.

\section{It Still Won't Work!}

He set to work quite quickly to build his accelerator, greatly helped by the fact that Rogowski had arranged for the work to be sponsored by the German Research Foundation. ${ }^{17}$ Rolf obtained a large transformer, about a metre high, from which he removed the secondary winding. He had a rather cramped and unattractive workshop in the basement, just a few cubic metres where the machine itself took up most of the space. The news that someone had managed to split the atomic nucleus had caused him concern. In one of his student notebooks he had written that one needed 'at least 10 million volts and possibly more' to split heavy atomic nuclei. So he had come to the conclusion that the only way to accelerate particles to such high energy was to build a piece of equipment like a transformer:

If there was a vacuum in the tube there would be hardly any electrical resistance and the electrons would very soon reach a very high speed as a result of the acceleration produced by really high tension. I was soon convinced that it would not take a long time for the electrons to approach the speed of light, and that classic formulae would then no longer apply ${ }^{18}$. 
There would need to be a vacuum in the tube, so that a magnetic field acting within the tube would generate current. If there were electrons in the tube, they would be affected by the magnetic force in the same way as the flow of electrons in a secondary winding. He realised that if the electrons travelled in a straight line for a short time they would hit the wall of the tube. So he would need somehow or other to compel them to travel in a circle. He knew enough about magnetic fields to realise that he would have to apply an additional magnetic field that would steer the electrons round a circular course.

But then there was the additional complication that the electrons would be accelerating, moving faster and faster. So the magnetic field would need to be made stronger to hold them on course and adjusted according to the acceleration of the electrons. This was the idea underlying the 'radiation transformer' which later came to be known as the betatron.

He got help from the glassblowing workshop to make the glass tube as he wanted it, in the form and size of a flattened doughnut or a transparent lifebuoy. After he had inserted the tube into the machine, the next thing was to create the magnetic fields. The difficulty was locating all the components in the right relationship to each other. He calculated the strengths of the various magnets required to control the electrons in their course and developed a technique to measure the relationship between the main magnetic field and the steering field. This enabled him to adjust the fields. He developed a theory of how the magnetic fields must be placed in relationship to each other so that they would propel and steer the electrons round the circle. This was later called the Widerøe Condition or the Widerøe Equation.

Now he can begin to test the machine. We are still in the year 1926. Will the electrons go round the circuit as the theory says they should? They don't. They go round one and a half circuits and then stop. He tries adjusting the magnetic fields, but no matter what he does, he cannot get the accelerator to work. Finally he has to go to Professor Rogowski and admit defeat. The professor, who is results-orientated, is adamant that he can't be awarded a doctorate for an apparatus that doesn't work. The idea was good enough, but Rolf has not managed to apply it in practice. The circular radiation transformer-his youthful dream-doesn't work.

\section{Needs Must}

What now? Young Rolf was a far-sighted strategist who didn't give up. $\mathrm{He}$ was also a pragmatist. So he put the idea of a circular accelerator aside. The promising, rather determined doctorate student visited the library and 
looked out an article by the Swede Gustav Ising that he had come across before. Two years previously, Ising had suggested an alternative method of accelerating charged particles but had not built a machine himself. Perhaps his method deserves a closer look? It was based on what was called 'multiple acceleration,' consisting of repeated bursts of acceleration. A particle gets a push, moves to a new point, gets a further push and so on, the speed increasing with each stimulus. Rolf studied the principle and speculated further. How can I locate these stimuli in exactly the right place to achieve what I want? Then he tackled all the other questions, one by one.

Rolf concentrated on the straight line accelerator, and got it to work according to plan. He has made the world's first linear accelerator. The foundation has been laid for the twentieth century's amazing development and construction of accelerators. Used in cancer treatment, materials testing and further atomic research. Throughout his life, Rolf remained grateful to the Swede who had set him on the right track. ${ }^{19}$

Rolf completed his thesis and called it 'About a New Principle for Generating High Voltages.' In the original language: Über ein neues Prinzip zur Herstellung hoher Spannungen. In the first part he describes the working linear accelerator that he has built. He gives a detailed description of the principles he has applied, the underlying mathematics and how the machine works. In part two he writes about what he has not yet achieved but which is his predominant idea, the circular accelerator for which he has thought out the solution but for which he has not managed to construct a machine that works. He still thinks that the theory is valid. He is working on it step by step. I am setting myself a hard task, Herr Professor. He writes a detailed account of the theory and of his work trying to construct the machine. $\mathrm{He}$ also includes what later became known as the Widerøe Equation, the 2:1 relationship between the acceleration and the steering magnetic fields. But he has to conclude disappointedly that the circle-shaped method didn't work. Nevertheless, whether the track be round or straight, his thesis contributed something quite new to physics.

This time, on 28th November 1927, he was awarded his doctorate of engineering, the first of several doctorates. His work was published in the journal Archiv für Elektrotechnik the following year. However, his work did not receive the acclaim that might have been expected. It wasn't just that Professor Rogowski, who had had such faith in him at the start, was no longer seriously interested in what he had done. 'I don't think he even so much as looked at my linear accelerator.' More significantly, the timing was wrong. Experimental nuclear physics was not yet an established field of 
research, and the technology was not yet sufficiently developed to overcome the challenges he faced. He was before his time.

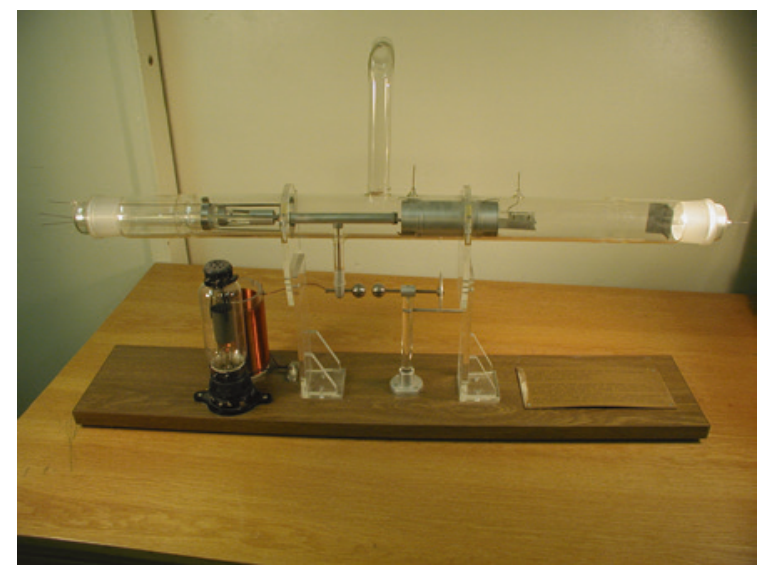

Exact replica of the first High-Frequency Linear-Accelerator successfully built and operated by Rolf Widerøe in Aachen, 1927. On display in a glass cabinet in the Norwegian Radium Hospital's vestibule. (Photo Knut Bjerkan)

\section{Headhunted}

In contrast, the industry did recognise his talents. In March 1928 he moved to Berlin and began work as an engineer with AEG. It had been rumoured that he was able, and he was offered jobs both in Norway and in Germany. He chose to go to AEG's transformer factory, where he would be working in industry rather than in research. AEG was involved in developing electricity supplies, building power stations, setting up high-tension cables and other things that Rolf understood. His job would be to build relays, switches that direct electrical current to selected cables rather like points on railway lines, and that cut off the current in the event of significant faults. These were distance relays, designed to protect the generating plant from damage by failures of current flow in high-tension cables. Such interruptions could be caused by many things, including trees falling on the line. The monitoring equipment would be used to show where the break was and how far it was from the monitoring site. The relays could also show the location of the break. AEG was the market leader in relays but there were problems with them, and Rolf immediately set about looking at the possibilities for redesigning them. 
He liked the city, and he had come right into the middle of a stimulating scientific environment. In 1929 he took part in an international conference in Berlin with lectures by Einstein and other famous physicists who spoke about atomic power, the new big idea. After a while he moved over to a separate relay department that AEG was now setting up. ${ }^{20}$ Practical man that he was, he enjoyed making things that were useful, but he was also fascinated by having to think out new solutions to problems. The result was 41 German and 2 American patents from barely four years at AEG.

Rolf made useful contacts and worked with top people. The head of the department had developed a new type of distance relay in collaboration with a colleague from the Siemens factory, who at that time was regarded in Germany as the authority on high voltage technology. ${ }^{21}$ Rolf also got to know another physicist, Max Steenbeck, who worked with the expert at Siemens. Rolf and Max jointly registered a patent. Rolf would come across Max Steenbeck again later, but in much more dramatic circumstances. Rolf had a good relationship with his boss at AEG, and visited him again many years later. He also got on well with the boss's assistant ${ }^{22}$. He had suggested a new variant of how to design a relay, and Rolf was given the job of constructing it. The two of them were about the same age, and they subsequently maintained contact as friends.

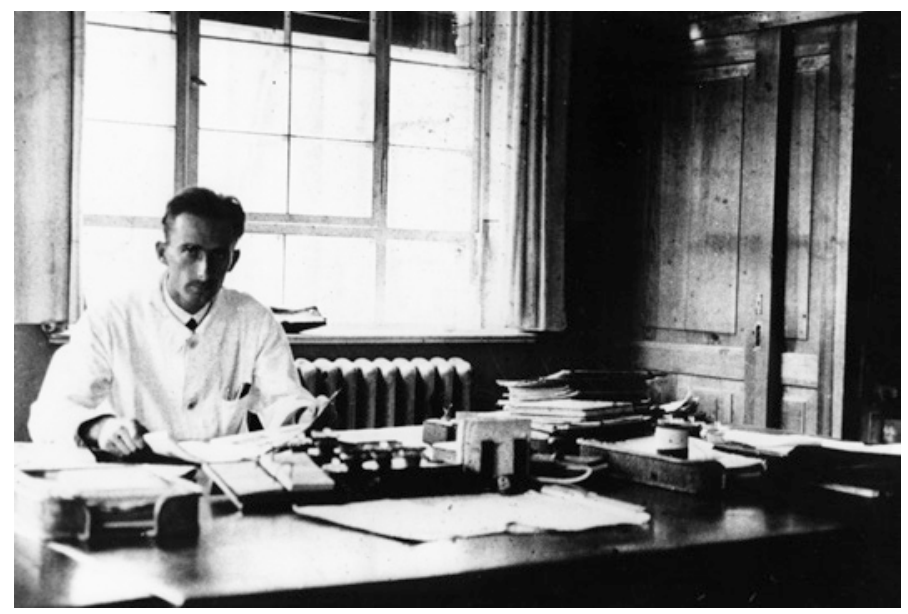

After completing his doctorate, Rolf Widerøe worked for four years with AEG in Berlin. (Photo Archives AEG) 
During his years in Berlin he also met Leo Szilard, the Jew who later wrote Einstein's famous letter to President Roosevelt warning that Nazi Germany might be researching how to make an atom bomb, the letter that is said to have initiated America's response in the form of the Manhattan Project. Little did Rolf realise then that he himself would be the subject of investigation in connection with the American atom bomb project. Szilard already had good contact with Einstein, with whom he had worked on a subject so mundane as refrigerators and had jointly registered a patent about refrigeration technology. An entertaining chap, as Rolf described him after a visit to a café together:

I remember when we were sitting in a café in Berlin and he told me about his high voltage project. He wanted to build several transformers on top of each other, and the lowest one would control the topmost. Lots of airy ideas, typical Hungarian, and enjoyable company. ${ }^{23}$

\section{Keeping an Eye on the Competition}

While he was at AEG, Rolf was able to concentrate on technology and set administrative work aside. He also put to one side his ideas about accelerators, but he did keep an eye on what other people were doing. Things were happening elsewhere in the world. In America, Lawrence was having success with his cyclotrons. Rolf's friend Ernst Sommerfeld kept him updated through his father who was now a professor in the USA. In the Carnegie Institute in Washington, machines to generate high voltages were being developed, by - among others - the Norwegian trio of Breit, Tuve and Hafstad, known as 'The Three Musketeers' ${ }^{24}$ and also another Norwegian, Odd Dahl, who was there for a while.

At Princeton University in New Jersey, the American Van de Graff was working on another type of accelerator. His machines were copied throughout the world and also manufactured industrially. Haukeland Hospital in Bergen acquired one of these. In Great Britain, Cockcroft and Walton had split an atomic nucleus with artificially accelerated particles for the first time, using a cascade generator. Lawrence was able to use his cyclotron soon after to confirm the results. Lawrence was awarded the Nobel Prize for Physics in 1939 and Cockcroft in 1951. ${ }^{25}$

Rolf was trying to keep up with his field of interest, but now he really wanted to come home to Oslo. Life in Germany was starting to become less comfortable. First there was the depression at the start of the 1930s. 
Workloads increased dramatically, and pay was halved both for himself and for his colleagues. As head of the department now he had to dismiss people, and he didn't like telling people he had trusted and worked with that they were no longer wanted. He felt awkward about sacking people when he was younger than them and also a foreigner. What disturbed him most, however, was the imminent change in the political regime. "Hitler was threatening to take over power, and I left Germany just in time before that happened,' he said. He was convinced that 'Alles zum Teufel gehen würde' ('Everything would go to Hell') with Hitler in power. ${ }^{26}$

He came home to Oslo at Christmas 1932. By the end of January, Hitler had taken over as Chancellor, suspended the constitution and replaced it with an emergency decree. The German people were denied freedom of speech and civil rights. Scientists could no longer do research freely and independently and public officials had to declare if there were Jews in the family. The Norwegian writer, resistance fighter and concentration camp prisoner Kristian Ottosen summed up the new situation thus:

According to paragraph one of the emergency decree personal freedom, the right of free expression, press freedom and right of assembly were legally restricted. The law permitted those in power to censure letters, post, telegraph and telephone communications. It was now legally permitted to ransack house and home and to arrest people who one suspected either had or intended to trade in contravention of one of the paragraphs of the decree of $28^{\text {th }}$ February. Using the authority of this decree, Hitler had all his political opponents many of the opposition in the Reichstag - arrested. The same fate befell leading members of the German civil service, leading academics and religious leaders. They were all branded as a threat to the German nation. ${ }^{.27}$

\section{Aeronautics and Airshows}

Rolf's brother Viggo and a friend had visited Berlin the previous October, to attend the international aeronautical trade fair. Germany was a world leader in flying technology, and they revelled in the exhibitions of aerodynamic details, polished metal and new records. It was five years since Lindbergh had flown over the Atlantic, and twenty-eight years since the Wright brothers' first flight. Propellers still provided propulsion, but the industry would soon be jetting into a new age when humans would master the air as they had mastered the land and the sea. Viggo returned home inspired by visions. Later, when he sat in a German prison writing about the experience on toilet 
paper or whatever paper he could get hold of, he described these happy days in enthusiastic terms:

The exhibition was a temple for us. Seeing what had been achieved strengthened our belief in the future of flight. It gave us confidence. As we walked between the rows of seaplanes, sports planes and commercial aircraft, big ideas began to take shape. Our country would become a major power in the air, as our ancestors had made it a major power on the sea. As our flag was carried over the seas of the world, so would it be carried through the air to distant lands.

We saw high heaven above our dreamland of flight. We imagined a wide, sun-soaked plain - Ekeberg was where we had in mind. - We placed everything together there: hangars; workshops; factories. Commercial planes and training planes were lined up in rows. We also put gliders there on the green grass, and others were soaring through the blue skies. Flights came and went. The Oslo Valley lay below in the summer mist, with the ford glittering in the sun beyond.

We had also developed a base on the island of Sjursøya, where big flying boats touched down from their travels before ploughing across the waters of the fjord and winging into the air again.

Oh, those happy days at Kaiserdam, when our mood was still confident and our dreams uninhibited. ${ }^{28}$

Yes, they would create an airline. Norwegians would be told about the wonders of flight and the possibilities of air travel. Model aeroplanes, gliders, flying as a sport, air taxi services, postal flights, scheduled airline flights, not to mention marketing and lobbying - they would need to master and accomplish all these things. Just look out, here we come. Like an echo of big brother.

Over Christmas, Viggo and Arild and three other young men who were mad on flight met in a flat in Schultzgate in Oslo. ${ }^{29}$ They put their ideas, courage, adventurous spirit and aeroplanes into a magic pot. The strategy that emerged was to give talks and arrange airshows throughout the country, combining the public relations exercise with taking on contracts for passenger flights that would generate income. They would need to find starting capital and acquire more planes, but that would come.

The first flying demonstration was scheduled to take place at Sundvollen beside Steinsfjord in Ringerike on 12th March 1933 at 1 p.m. ${ }^{30}$ Viggo has left us a detailed description of the dramatic start of the event: 
When we opened the curtains on Sunday morning at Norderhov vicarage, it was snowing heavily. The mood at the breakfast table was tense, as if a fiasco was looming. The fact that the planes were at Bogstadvannet near Oslo didn't make the mood any lighter. How would they manage to come across Nordmarka in this weather?

The pilots who were due to come from Oslo were just as concerned:

(...) As the pilots approached the starting point for the demonstration, they became less and less confident that flying would be at all possible. The only break in the white snowfield was the vehicle for towing the glider. It stood stuck in half a metre of new snow. Optimistically, everybody set about tramping a surface on the runway, digging out the vehicle and advising people not to go home. There would be a flying event, they said, 'Flying is going ahead as planned.'

The sound of the planes was heard at five to one. (...) They had found their way up Sørkedalen and jumped from lake to lake across Nordmarka without coming to Ringerike, where the weather stood like a wall over everything. Eventually they had found a line of power cables which they followed down to Steinsfjord.

The demonstration did take place, with spins from 350 metres, rolls, flying upside-down, stall-turns, formation flying, gliding and balloon competitions where the pilots vied to burst the most balloons with the propeller. The spectators were excited, and despite the challenging weather the very first airshow was a success. ${ }^{31}$

The next show took place the following Sunday at Akersvika near Hamar. School classes came midweek to hear about planes and flying, followed by a taster flight and finally writing about the experience. The local press also took part. There was publicity for the flight project in town after town throughout the winter, and as Viggo later remembered as he sat in his cell during the war and thought back, there was brilliant sunshine and high spirits every single time after the first unfortunate snowy weather at Sundvollen.

\section{The World's Best Relays}

To dream, develop an idea, plan, invest, overcome difficulties- these traits all lay in the family genes. Rolf was also interested in flying, but he had more than enough to do with his own ideas that he had brought back from 
Germany. His electrical relays should be improved even more, according to plans he had developed during his time at AEG. The distance relays they produced were the best currently available, but they were not especially accurate and not really sensitive, even though Rolf had further developed them during his time there. His new design was both faster and more accurate, more reliable and easy to use. He was well informed about the state of development of electrical power in Norway before he came home and he knew that the many small power stations that were now being connected together in a combined distribution grid needed such distance relays. They would need to be simple and robust, as many electricity companies used unskilled workers and complicated precision technology was impractical. The task was clear; to create the world's best relays for use in the Norwegian power stations.

Several months before he came home he had sent an article to the Electrical Engineering Journal in Oslo. Over almost 15 pages, he described the new situation the power industry was in and the great possibilities that the grid connection could offer. For many people, these were novel and exciting ideas. This is the power engineer speaking out, but also the PR man-just like his brothers who were trying to convince everybody of the great benefits of flight. He described how the industry had developed and he addressed both the consumers and the providers:

In the early days of electricity transmission it was a relatively simple matter to protect the lines and the machines against short-circuits and overloads. The power stations were mostly linked directly to their major users and there were no connections between different power stations and different users. Indeed, the very idea of a shared power distribution network with $\mathrm{x}$ power stations feeding energy in and y users taking energy out was unfamiliar at that time. The lines were protected on a simple cut-out principle; when the current in a cable rose above a chosen maximum level, the lead was disconnected and the user was left without power. This is the same principle as is still used in domestic installations. ${ }^{32}$

But now the electricity supply systems were being connected together over larger areas into a shared network. This had advantages for all parties:

This sharing of the network is a benefit for the users. They can now be provided with power through more supply lines, so that they will not have a power-cut if one of the lines fails. It is also of great benefit for the various power stations. First, they act mutually as back-ups for each other and second, 
when the flow of water is irregular they can use the network to even out production and maintain regular power supply.

But there were disadvantages too. The combined generator output can become very high. When the grid is receiving energy from all the power stations there can be a heavy load on the switching mechanisms in the event of a short-circuit. This problem had long since been solved, Rolf wrote. But then there was another problem about levelling out the current flow, namely that a fault in one line would affect the whole network. If there was a short-circuit at one place, all the supply cables would cut out and all the users would suffer a power-cut. The effect of this was that the more the grid was extended, the more frequent became the failures of supply. Therefore, he wrote, two requirements must be specified for all relay systems: first, the short-circuited cable must be able to be disconnected independently of the others, so that only it and the nearest switches were cut out; and second, the interruption of power supply must be as short as possible.

Then he described the different types of relay one by one. This was popular science and technical description combined, explained simply and modestly. He enjoyed his role as an interpreter of scientific technology to the general public and he had inherited a sense of how to present the good news. He maintained this straightforward style of presentation for his whole life and especially when he was lecturing and had an audience he presented his topic with enthusiasm.

\section{Onwards and Upwards}

Back in Norway, he had selected N. Jacobsen's Electrical Works in Oslo as the place he would like to work. Jacobsen had made crystal sets and was well known for 'the people's receiver,' the radio the firm produced for NRK, the Norwegian Broadcasting Corporation which was established the same year. Rolf contacted the director and convinced him that his relays were the right ones for the Norwegian situation and that Jacobsen should manufacture them. He negotiated a salary of 500 kroner per month, which he thought was good, and started on 1st April 1933, two weeks after his brothers' airshow at Sundvollen.

He soon got production started. The relay turned out to be cheap to build, and the result was good. He developed a gadget that was more accurate than previous models but had no over-sensitive fine mechanical parts. It 
also reacted quickly, within $1 / 25$ th of a second. This was important, as otherwise the generators in the power stations would fall out of synchronisation and the whole system of interconnected power stations could fail.

The new relay was ready by the autumn and Rolf went on a combined holiday and sales tour in his Ford A to England, Spain, Italy and Germany. He often slept in the car. In England he visited a colleague, Torvald Torgersen, who joined him on the trip. Then the tour took a dramatic turn. Torvald fell ill with typhus and Rolf caught paratyphus, but they came home safely and Torvald later bought himself a summer cabin just beside the Widerøe's family property on the Oslo Fjord. Whether or not it was the result of salmonella bacteria, Rolf decided that a career as a travelling salesman was not for him.

In March he carried out the first tests on a power line in Vestfold. He then wrote another article for the Electrical Engineering Journal, in which he once again described the need for new and better relays-and uninhibitedly advertised his own and Jacobsen's newly developed design:

We found, however, that not all existing relays were suitable for Norwegian situations. The relays were too delicately built, they needed a lot of attention and above all they were very expensive. (...) The situation has however now entered a completely new phase as N. Jacobsen's Elektriske Verksted A/S is bringing to the market a new, Norwegian distance relay, designed and manufactured in the first instance to satisfy the needs that were expressed at the relay conference in 1932 . The relay is based on a completely new, Norwegian invention (Norwegian patent registration no. $52417 \mathrm{R}$. Widerøe), and N. Jacobsens Elektriske Verksted A/S has become the first manufacturer of relays here in Norway. ${ }^{33}$

\section{The Brothers Take Off}

While Rolf had been travelling round Europe to promote the sale of relays, Viggo and Arild were continuing their PR stunts to promote enthusiasm for flying. When 6,000 people were bathing at Ingierstrand on Sundays, they held a flying demonstration there. When whole families had gathered at Bogstad Lake in winter to go skating, they were there with balloons and talks. Their urge for adventure didn't stop there, and they decided to fly to Africa. They read all they could find, collected maps and sought out information about landing stops on the way. This was a long journey that needed thorough planning. But the money didn't stretch to it, and a film script they 
had prepared also had to be set aside. Another rather high-flown plan was to fly round the world in a Lockheed plane, but they managed to control their ideas to concentrate instead on acquiring aircraft that could be used for utilitarian purposes in Norway.

They got hold of what was available: several surplus planes from the navy and a glider from the Aeronautical Club. Also, one of their colleagues already had his own plane, a Gipsy Moth that was useful right up until it was wrecked in the mountains one Easter. If they were to invest professionally and commercially, they still needed a proper aeroplane. In December, Viggo travelled to the USA and bought a five-seater Waco seaplane. The problem was how to get it home to Norway. The costs of packing, various loading and unloading and then transport by ship to Norway were too great. The solution was to start by flying it to New York. Such a trip was verging on hazardous, but he could cope with that and it made a good story afterwards:

The weather was dreadful, with the cloud base at 100 metres, mist, rain and icing. It was an exciting trip among the skyscrapers looming up in the mist and over bridges and parks. Fortunately I had a local guide on board, who counted off the streets and nodded approvingly every time a familiar skyscraper soared up. By the time we landed we had almost an inch of ice on the leading edges of the wings and the rudder, and the engine had started vibrating significantly because of ice on the propeller. ${ }^{34}$

Safely arrived, the seaplane was loaded onto a barge and towed to the $S S$ Europa, which took it across the Atlantic to Bremen, ready to be flown home from there. This was a rather exciting flight too. He obtained permission to take off directly from the quay, and flew through thick snowfall, following the railway line towards Hamburg, where the complications really began. The customs had re-stowed some of the spare parts, which had altered the adjustment of the compass:

I flew by my instruments for four hours, in and above the layer of cloud, without seeing any sign of the clear weather that had been forecast. I had only half an hour's supply of petrol left, and I had to take the chance of going under the cloud level to orientate myself. I came out of the cloud at 50 metres, above a railway line which I followed. I was very surprised to spot a German flag and then to read a German name on a railway station as I passed. According to my instruments I should have been somewhere near Gothenburg. After an emergency landing, it turned out that I was near Stolp on the boundary with Poland. 
When the aircraft was in place in Norway, they could start the airline company. Things now happened quickly. Viggo is 29, Arild 24. Why hesitate? On 13th January 1934 they held their founding general meeting. All three of the brothers were there - Rolf, Viggo and Arild - plus their father and two of his friends. Theodor had proxy votes on behalf of his wife Carla and Uncle Sofus. Viggo was exercising another three proxy votes. Theodor, who had been sponsoring the project for a long time, followed the protocol. Widerøe Airlines was founded. Today, over 80 years later, it is one of the oldest airlines in the world still operating.

Now that they were formally in business, Viggo was appointed Managing Director. He said modestly that that was because he was the only one who had a telephone, and that that was why the company was named after him. In reality, everyone knew where the power lay and the choice was hardly difficult. More planes were acquired in the course of the year. ${ }^{35}$ The flying demonstrations continued. There were air-ambulance missions and other work. The planes had their admirers, and so did the hostesses. On an air-taxi trip to Ustaoset Hotel at Easter 1934 one of them was the hotel manager's daughter, Solveig Schrøder, who married Viggo the following year.

\section{Dance of Love}

Making the world's best electrical relay was not the only dream in Rolf's head when he came home from Germany. He also wanted to find himself a wife, and he set about this in his characteristically methodical way. $\mathrm{He}$ enrolled in Miss Fearnley's Dance School, ostensibly to learn the newest dances. He could dance, but this was the new age of quickstep and slow foxtrot and tango. Luck was on his side. At the dance school he met Ragnhild Christiansen, who lived at Ullern, not far from his own childhood home. They were married on 14th November 1934. ${ }^{36}$

Ragnhild also came from a big family, with four sisters and one brother. Ragnhild was the eldest. Her father, Alexander Christiansen, became a Nazi during the war. This was not much spoken about, but it was mentioned sufficiently for Rolf and Ragnhild's youngest son, Rolf jnr. who was born in 1941, to sense that there was something unusual about this grandfather. He was a prosperous businessman until something went wrong, and he later tried energetically to defend himself. His Nazi affiliations became a problem for the family, but in the 1930's the preoccupations of the Widerøes in Borgenveien and the Christiansens in Ullernveien were with marriages and baptisms. 


\section{The Fishermen Set Their Clocks by Us}

The Widerøe family's airline was well established by the time the war started. Acquiring the green Waco had been a decisive step. The colour had not been of their choice, but had been how the plane was delivered from the factory. Viggo had dreamt of a 'silver bird' with red lettering, but he had neither time nor money to wait for the right colour and he just had to take what he could get. On 15th June 1934 the company was awarded the concession for the Oslo-Kristiansand-Stavanger-Haugesund route. Three days later, at 07.50, the Waco left its berth at the seaplane harbour at Ingierstrand with Viggo at the controls and took off for Kristiansand fully laden with passengers, goods and post. The new age of air traffic in Norway had begun.

The routine was not always glamorous:

These were long days for the aircrew. The trip to Haugesund usually took five hours and ten minutes. We got back to Ingierstrand at 19.30, but by then we had also been down to Vannsjø near Moss to deliver international mail to the train. Then the mechanics worked on the planes all night so that everything would be ready for next morning. Our flights ran on time with 100 per cent regularity and the fishermen used to set their clocks by us. ${ }^{37}$

The original green colour became part of the company's identity. Shortrunway airfields were also developed and people in Western and Northern Norway became familiar with the Twin Otter, Dash 7 and Dash 8. It has been said that Widerøe's small aircraft united coastal Norway. The districts valued them and thought of them as their own.

Viggo's trademark was the capacity to think in the longer term. One of his successors in the airline characterised the founder as the type who never gave up. ${ }^{38}$ The same could well be said of his brother Rolf. They both had lofty dreams, but both of them combined this visionary thinking with hard work. One of them was busy transporting people and post, up and down, North and South in all sorts of weather, struggling to maintain 100 per cent regularity and have money in the bank. For the other, it was a series of formulae, investigations, up-turns, down-turns, sales promotion and fine technical detail. Year in, year out. With success in sight far ahead in the distance. 


\section{Grasp the Opportunities}

Viggo was both an adventurer and a responsible businessman, spurred onwards by encouraging moments as his venture progressed. It was a matter of grasping the opportunities as they presented, for example in the form of a commission in the polar seas when whale trader and consul Lars Christiansen invited him to join an Antarctic expedition in 1936. Viggo recalls:

He wanted to send an expedition to Antarctica to chart the unknown coastal region between $80^{\circ}$ East and $10^{\circ}$ West. Aerial photographs of the coast would be put together to make maps of the previously unknown territory. (...) I was given a free hand in the selection of personnel and choice of equipment. Only one condition was imposed on me - that everything should be first class. ${ }^{39}$

They were in the Antarctic for two months, living on a whaling ship and flying over the ice whenever the weather allowed. During this time, they photographed about 2,000 kilometres of coastline. On one occasion they almost came to grief. His aviator daughter, Turi Widerøe, has described the incident clearly and soberly:

Because of a misunderstanding, the mechanic had not put in enough petrol. They flew $450 \mathrm{~km}$. east across the land and then started taking photographs. They had been flying for about four hours when the pilot realised that there was hardly any petrol left in the tanks. They switched off the camera and set course directly back towards the whaling ship, where the people on board had been warned to be prepared for an emergency landing. (...) The sea-ice conditions had deteriorated while they were in the air. (...) The landing space was no bigger than two boat-lengths when they arrived. The pilot managed to bring the plane down and they were hoisted on board immediately. By the time they had taken their flying clothes off the ship was surrounded by ice on all sides. ${ }^{40}$

The newly-weds, Rolf and Ragnhild, in the meantime followed much less exotic itineraries, but they managed to make their own excitements. The pair of them travelled round Norway in their free time selling relays to Norwegian power-stations and in the course of a year Rolf installed thirty of his distance relays. In the summer of 1935 Ragnhild worked alongside him at Jacobsen's Electrical Works. According to a true story which Rolf himself has recounted to several people, they were working there late one evening 
when Rolf was intensely absorbed in his calculations. Ragnhild was sitting in the neighbouring room. Rolf opened the door, looked in and said 'You can go home now, Miss Christiansen.' He had momentarily forgotten that they were married, eight months after the wedding. He said that Ragnhild never forgot this incident.

\section{Headhunted Two}

Rolf was a valuable asset to Jacobsen's Electrical Works, but his talents were taking him further. The electricity distribution authority invited six companies to put forward proposals for a distribution grid using the new relays. The six firms were Siemens, AEG, Brown Boveri, Compagnie des Compteurs, Westinghouse and Rolf's company, little Jacobsens. Rolf's company won the contract, convincingly. His comments were laconic: 'My relays were quicker, more accurate, more robust and also cheaper than all the competitors.'

In securing the sales deal for Jacobsens, Rolf had also sold himself. The American company Westinghouse wanted to get hold of the man who almost single-handedly had won in competition with European giants. The director of the Norwegian daughter-company, National Industri Westinghouse, came to see him one day around New Year 1937. The firm had a transformer factory in Drammen and an office in Oslo.

Rolf was given the impression that he would take over the manager's job. He accepted the offer and started with National Industri in April. However, the position was a disappointment and he only stayed there for three years. Most of the work consisted of repairing equipment that the company had had manufactured elsewhere. Servicing and maintenance, in other words, plus time spent on sales. This didn't suit him at all; he was unhappy and didn't conceal his feelings. Es war für mich keine glückliche Zeit, ('It was not a happy time for me'), as he said clearly in a German interview many years later. At Jacobsens he had published eight academic papers, at National Industri not a single one. He still gave a few lectures, including a lecture about relays at a Nordic engineering conference in Copenhagen. He became frustrated:

Typical! I was as if in cold storage at National Industri, as if dead. I obviously gave a few lectures about high-tension leads, but there were no real challenges. ${ }^{41}$ 
But things are never so bad that there is not some good to be found. At home, he now had a one year old daughter and he had more time to be at home with her and take lots of photos. Their first son was born that year, and family life was recorded in photo captions. 'Arild in the pram in the garden,' 'Arild crawling' and 'Arild learning to walk.' There are also mother's pictures of the proud father on the lawn with their son and father's pictures of the proud mother jumping for joy with Arild on her shoulders. Pictures of Unn's tricycle and of skis and the toboggan. Another son soon followed. Birthday parties with neighbouring children, children in the sand-pit, children on fishing trips, children in the boat. Children, brothers and sisters, aunts, uncles and grandparents bathing at the family's country home. Rolf went on ski trips with his sisters, went skating on Bogstad Lake near his brother's aviation workshop and celebrated Easter with his wife's brothers and sisters in the hills at Ringebu.

On 1st August 1937 a tragedy struck the family. The first one. They could speak about this one. At the age of 29, Arild died. Arild, who was so happy and whose future looked so bright. Arild, who was so meticulous and careful about safety when he was flying. Arild, of whom his brother Viggo wrote: 'In he air, he was the most careful of us all.' ${ }^{42}$

The plane was new, but there was an undetected metal flaw in the wing. I wonder if older brother Rolf may later have asked himself whether if he had continued what he started and built the amazing accelerator that only existed in his head, the flaw in the wing might have been detected. He only found out later that accelerators could be used among other things to test materials and find weaknesses in metal by penetrating it like an X-ray. Such are the ironies of fate and the strange thoughts that come together when someone dies. I hope he didn't think like that; it wouldn't have helped. None of the five who died would have been saved by Rolf berating himself and being wise after the event. Even if such a machine had existed, neither the aeroplane factory nor the Widerøe workshop at Bogstad would have had one.

A question that I know he asked himself in his older days and surely also wondered if others were asking themselves, was why he had not continued working on the accelerator when he completed his doctorate. A few great physicists, especially in the USA and England, were researching intensively. But life is lived forwards, not backwards. When he finished his thesis in 1927, he didn't know that somebody would get a Nobel Prize for developing his idea into practical application. At that time, it was a question of finding a job and then starting a family. There wasn't time for experimentation. 
While he was working on his thesis he didn't have much contact with other institutions working in the same field. Neither Rutherford's laboratory in Cambridge, nor the Radium Laboratory at Berkeley. He just didn't know of others working on the same topic. He heard and read about this subsequently and understood that he had been in on one of the great ideas of the time, but at that time the only use he could envisage for particle accelerators was to split atoms, and he reckoned that lay a long time in the future. Twenty or thirty years later he said it even more strongly, even though it didn't sound wholly convincing:

In fact, at that time I was not particularly interested in the possibility of using high energy electrons to produce stronger X-rays, or rays that could penetrate deeper. So I wasn't thinking about X-rays, either for material testing or in medicine. At the time, I considered my work in Aachen as completed and turned my mind to other projects. ${ }^{43}$

\section{The USA Takes up the Thread}

The first practical application of Rolf's doctoral thesis was when the American Ernest O. Lawrence invented the cyclotron. Lawrence had Norwegian parents and his real name was Larsen. He grew up in a Norwegian settlement in North Dakota and attended the Norwegian St. Olav's College in Minnesota. The cyclotron was a follow-up of Rolf's ideas, a round particle accelerator that prepared the way for new gigantic atom-smashers. Lawrence was always careful to acknowledge Rolf. He knew where the theory came from, and he never discarded his hand-written notes from when he had come across Widerøe's method of accelerating electrically charged atoms.

Lawrence told Rolf himself about the time when he had been attending a conference at Berkeley soon after he had started there. He had become bored and had left the conference hall to go to the library instead. There he had more or less randomly picked up the journal Archiv für Elektrotechnik with the article about Rolf's doctoral thesis. He didn't know much German, but he understood the drawings and the equations. Rolf thought it was good that Lawrence had not understood the text, for then 'he would have got to know about my stabilisation problems' and not persisted. In this way, Lawrence understood the main principle and was able to bring accelerator research the next step forward. It gave him the idea of building the world's first cyclotron. 
In American universities, rumours circulated that as soon as Lawrence had seen the article he knew that he would manage to solve the problem even better than Rolf had done. He was said to have run back to the laboratory, bumped into a colleague's wife on the way and shouted out aloud, 'I'm going to be famous! I'm going to be famous!'

Rolf met him many years later and described him kindly as temperamental, headstrong and enthusiastic, and added as yet another positive that he was ready for adventure. Together with his assistants in California, Lawrence had begun by building a linear accelerator but had proceeded a little differently from Rolf and managed to generate significantly higher energy with much lower input. 'Fantastic,' commented Rolf. Eventually Lawrence started to develop a spiral path instead and so invent the cyclotron. Rolf immediately saw that this was the same idea as one of his assistants at the college in Aachen had been considering while Rolf was studying there. ${ }^{44} \mathrm{He}$ had asked Rolf if they could create a circular path, and Rolf had replied in terms of which he was later ashamed:

I replied that one could indeed but that it would be difficult to stabilise the circular paths, just as I later wrote in my thesis. Thus died a proposition for the cyclotron, and it was I who more or less dropped the idea.

In one of the lectures he gave in Norway, a very personal presentation at Geilo in 1983, he repeated this self-criticism:

Professor Flegler had really invented the cyclotron, but my doubt and premature judgement of the idea as a result of my experiments with the ray transformer killed his idea. So: Beware premature judgements!'

Lawrence built his second cyclotron, a little bigger than the first, 10 inches in diameter. With this he could accelerate protons up to one million electron volts and confirm what had earlier been observed by Cockcroft and Walton in England. The third cyclotron was even bigger, with a diameter of 27 inches. This could accelerate heavy hydrogen nuclei, a component of heavy water, up to five million electron volts. The age of atomic physics had begun.

Rolf still didn't throw himself too quickly into accelerator research, mostly because he was pre-occupied with other things. These were the years when he was building up a career in the Norwegian electrical power industry. He did however follow developments from the sidelines and develop his own ideas. He didn't always agree with those he admired, including 
Lawrence. One point of disagreement was the size of magnet being used, and even non-scientists can get some insight into this by reading about his thoughts:

I came to the conclusion that this was not the best way to achieve higher energy. The spiral paths in these accelerators require a magnetic field covering a large area, which can best be created using an iron yoke. Not a big problem so long as the energies are not too high. But on the other hand, if you want to reach higher energies you will soon reach a new limit imposed by the weight and cost of the magnet itself. My ray transformer met the same problem. The magnet needed to accelerate to higher energies would have been altogether too big. ${ }^{45}$

He also thought about a method for solving this problem, even though it would be many years before he could prove it:

I hoped nevertheless to be able to hold the particles in a relatively narrow ringshaped tube, like the situation in the ray transformer, and still be able to accelerate them. (...) and so my thoughts went in that direction. But this remained a dream. I never followed this up seriously until later when for purely personal reasons I found time for it, and that was not until 1945.

\section{Big Science}

The Berkeley laboratory was the source of other important inventions in the 1930 's in addition to the cyclotron. Many people contributed to these, not least Louis Alvarez, another of Lawrence's assistants who battled with the same problems as Rolf. Subsequently, the fundamental structures in accelerators have been considered as being of two types: Widerøe's and Alvarez'. The work done at the Radiation Laboratory, 'Rad Lab,' at Berkeley and at certain other nuclear physics centres was the start of what came to be called 'Big Science.' This term refers both to the magnitude of the topics, and to the size of the research teams required to tackle them. What was especially new was the size of teams. When it comes to big questions such as what the Earth consists of or what are the very smallest particles, one person working in a laboratory is no longer enough. The term 'Big Science' arose during the inter-war years because of the need for heavy technical equipment, big budgets and large teams of scientists working together. The research also had a practical value that was not of equal interest to everybody, and Rolf had 
his own clear understanding of the motivating power behind the American contribution:

For Lawrence, the motivation was to build accelerators, especially cyclotrons. It was as if he was obsessed by this, and all his efforts were directed towards it. But for his younger colleagues, assistants and students, splitting atoms and nuclear physics were sufficient motivation to build bigger and bigger machines. I think that this was also the case with Rogowski when he supported my ideas for a six million volts ray transformer. He was a highly educated, extremely intellectual man with a very lively imagination. We never spoke about these possible applications, and I didn't mention them in my thesis.

It was probably too early to mention such things at that time and it would not have been considered serious physics. It would probably have been thought of as science fiction. In my thesis I wrote cautiously: 'It is possible that high-energy ionised radiation might have significance for physics.' Really a bit of an understatement, for ever since 1919 the splitting of the atom had been the main motive behind my interest in high-voltage technology. ${ }^{46}$

The approach of the Second World War added urgency to the research. The Berkeley Laboratory started a rapid programme to build cyclotrons, summarised thus in their own archives:

In September 1939, as the Nazis started World War II, Lawrence announced plans for a $100 \mathrm{MeV}$ cyclotron. A tight bond developed between the two events. Fear that German scientists might contrive a bomb on the principle of nuclear fission introduced by Lise Meitner and Otto Frisch in January 1939 provoked a crash program to build one here, and the magnet for Lawrence's new accelerator, completed as a wartime priority, helped to develop the machinery for making the first nuclear explosives. The mobilization of the Laboratory brought irreversible changes in its size, scope, and corporate life. It became the embodiment of big science. Its pre-war development had provided a base on which the temporary expansion demanded by the war could not only take place, but take hold. ${ }^{47}$

\section{A Sponsorship Campaign}

Norwegian physicists were also interested in the big discoveries that were being made in the first part of the twentieth century. Already at the beginning of the century there was a society that arranged lectures on Kristian 
Birkeland's northern lights experiments and where Professor Ellen Gleditsch, who had trained with Madame Curie, spoke about Rutherford and radioactivity. It would still be several years until 1938 when the Physics Society at Oslo University was founded and started publishing the journal Fra Fysikkens Verden ('From the World of Physics'). Rolf was not one of the group of physicists around Oslo University in the 1930s, but he knew Olav Netteland well. Netteland worked at the Physics Institute and was on the journal's management committee, which also functioned as an editorial committee. When the sponsors withdrew at the last minute and the publishing initiative seemed destined for failure, Rolf came to the rescue with his industrial contacts. He persuaded his employer, National Industri, to donate 5,000 kroner to the society and also collected several hundred kroner towards the publication of the very first issue in summer $1939 .{ }^{48}$ The editor was Egil Hylleraas, a high-ranking professor and head of the theoretical physics department at Oslo University.

Rolf would meet Hylleraas many years later in a rather different context, but if anybody had been able to predict these later events at the time, they would have seemed not just unlikely, but totally absurd. Rolf wrote for the journal in the early years and subscribed to it throughout his life. He reckoned that some good had come from his job at National Industri, as it had contributed to the financial rescue operation for the journal.

When Rolf was interviewed at the age of 81 by a group of young Norwegian physicists, they asked him if he had thought about staying on in Germany after completing his studies and his job at AEG. Would that not have given better career prospects than going into the Norwegian power industry? His answer was a clear 'No!' Hitler's rise to power did not suit him at all. He had had enough of everything German and wanted to go home, and he had never regretted that. He had been able to spread his wings at Jacobsen's, though admittedly not at National Industri, and there had been other benefits. He was in his best years, he was well educated and he had his family, his own house and even a car.

The fact that he was not finished with Hitler when he moved from Berlin to Oslo in 1932 was one of the ironies of fate.

\section{Headhunted Three}

In his job at National Industri, Rolf had contact in Oslo with NEBB, Norwegian Electric and Brown Bovery, a daughter company of the Swiss firm Brown Boveri \& Co. In spring 1940 he was offered a position in 
NEBB, as head of the department that supplied equipment to the power industry. Rolf assumed that this had come about through contact between his boss at National Industry and the director at NEBB. He took up his post in June.

A job in the developing power industry was very appropriate for a man who in his time had written a student essay on 'Voltage distribution through isolator chains in high tension lines.' The high voltage engineer could now show his talents. He earned a reputation for being a good problem-solver, the man to call when things were difficult, a man who saw technical problems as challenges to be overcome. Rolf was effective, got good feed-back reports and generally thrived. He did things his own way, with the result that he could be considered positively to have integrity or, rather more negatively, as being arrogant.

At a conference in Copenhagen he commented rather cheekily on Niels Bohr's opening address that 'I must have heard it, but I can't remember it at all,' and added that 'Bohr's lectures were always a little difficult to understand.' After the conference there was a guided tour of the institute, in which he did not take part. 'As I was in Copenhagen with my wife, I reckoned that I had other things to do. We were probably sightseeing somewhere or other.' You could say he was a little superior and rather laid back in his relationships with the great and famous. ${ }^{49}$

The science of electricity is closely related to the science of atomic power. Rolf was fascinated by this on several levels. It lacked research. It lacked dissemination of the research that had been done. The journal needed articles. So Rolf stepped forward again. He wrote an article for the second issue in 1940, 'Will atomic energy be technically useful?' In the article, he also refers to an article that the editor, Hylleraas, had written. The answer was a resounding 'Yes.' Atomic energy would be useful. Until recently the situation had been that scientists knew a lot about atomic energy, could make calculations and also release 'very small, technically quite insignificant amounts of energy. But the possibility of practical application of atomic energy seemed so distant that nobody considered this possibility and many thought the problem was totally insoluble.' He supported those who thought that they were now facing a breakthrough. In January 1939 German researchers had made 'a discovery that totally changed the situation:'

On the basis of this and other investigations we can now consider it highly probable that atomic energy can be utilised practically. There are still many conditions to be met and a series of processes to be investigated more 
thoroughly before we can give a definitive answer to the question. But if atomic energy technology is successful the world will undoubtedly enter a new era so different from the present that we can hardly imagine the changes to come. $^{50}$

\section{Doctor of Engineering}

Rolf's articles in the Journal of Electrical Engineering were written by 'Dr. Ing. R. Widerøe,' whereas his publication in the journal of the physics society at Oslo University gave his name simply as 'R. Widerøe,' without further degree or title. It is difficult to know how much significance to attach to this. His degree was not from Oslo University, to which most of the members of the society belonged, and academics do have a tendency to value their own institution above others and to undervalue expertise from elsewhere. This may be part of the reason why the industrialist Rolf Widerøe with his patented inventions never gained the same status in Norway as academic researchers who published on scientific matters. Any concern about him not being an academic was unfounded, for in his article on use of atomic power he starts by referring to Einstein's Theory of Relativity:

The discovery of radium and the study of radioactivity clearly showed that there are large energy sources concealed within the atom. The research carried out by Einstein and others cast new light on this energy, and in 1905 Einstein proposed the Theory of Special Relativity, of which possibly the most important result is the following: "Every mass corresponds to a fixed amount of energy and conversely, every form of energy corresponds to a fixed mass: $\mathrm{e}=\mathrm{mc}^{2}$.

He continued enthusiastically, and you don't have to understand the details to understand his enthusiasm and his support for those who now saw atomic power as the solution to the world's energy problem:

Thus we understand that the massive energy concentrated in atomic nuclei represents an Eldorado, an immeasurable and inexhaustible source of energy which, if it can be utilised, could satisfy humanity's hunger for energy for all time.

The article was written in 1939. But then something happened on the research front just as the journal was due to go to press. The Frenchman 
Jean Frédéric Joliot and his co-workers claimed that they had managed to prove that uranium could be split using a chain reaction. This news had to be included, and as the article was ready it had to be added as a postscript. Jean Frédéric was often at this time referred to as Joliot-Curie, as he was married to Madame Curie's daughter Irene, herself a chemist. When the couple wrote articles together they signed them with the double surname, even though he never officially took the name Curie. They had been awarded the Nobel Prize in 1935 and in his acceptance speech Joliot had, probably for the first time in history, referred to the possibility that chain reactions between atomic nuclei could be a future source of energy. Now they claimed to have shown how such chain reactions could happen, and that was good news for Rolf as an advocate for atomic energy.

In the article Rolf had sketched out grand scenarios where power stations could be fuelled more simply and more effectively with uranium instead of coal. He asked rhetorically: 'Will these amazing possibilities come to reality?' $\mathrm{He}$ referred to uncertain results and to research that remained to be done but he ended optimistically, for even if Niels Bohr's hypothesis had not yet been proven, Rolf thought there were grounds to 'assume that the question of the practical utilisation of atomic energy will be solved quite soon.' Then came the news of Joliot's successful attempt which he attached in the postscript dated February 1940.

Things now happened rapidly. By October 1940 a further post-script was required. In this Rolf summarised the latest findings, which confirmed what Bohr had said and what Joliot had discovered. He liked this. At the same time, one had to remember all the considerations that had to be taken into account. And-co-founder of an airline as he was-he remembered the significance of the weight of the fuel. 'So it is almost unnecessary to point out the revolutionary significance for air travel of a fuel that is practically weightless.'

His article showed that the road from particle accelerators in laboratories to relays in the power industry - and back again - was not all that long. It left no doubt that the author believed that atomic energy could one day become a practicality. ${ }^{51}$

\section{Was Right!}

Even though his everyday job was with relays in the Norwegian power industry, Rolf kept himself informed about the research that was going on in the wider world. For example at the University of Illinois, where Kerst, 
an American, managed to make the world's first betatron in 1941. What's more, it worked well. Was Rolf disappointed to hear this? Irritated? Angry? Sad? No. Should he feel frustrated and reproach himself? Not at all. Is it really true? Did he get it to work? No, you don't say! What a triumph! Donald Kerst has done it! The USA has really picked up speed on accelerator technology since Lawrence. So I was right after all! My theory was correct. Now it's in print, not just anywhere, but in Physical Review, no. 60, pages 47-53, in 1941.

This was 14 years after Rolf's pioneering work. The technology had now caught up. The system was stable. The electrons flowed round and round and round. On course as directed. They achieved an energy level that could only be achieved by an otherwise impossibly high voltage, 2.3 million electron-volts, or $2.3 \mathrm{MeV}$ in technical terminology. All this in a tube of only $7.5 \mathrm{~cm}$ radius. When everything had been done properly and all the parts put together correctly. But the principle, the idea, the invention; Rolf had thought this out as a 20 year old student in Karlsruhe and written it in his little notebook. It tallied, and had now been fully confirmed in practice.

In the USA, General Electric immediately snapped up both Kerst and the betatron. GE had made the doughnut-shaped glass tube to Kerst's specifications, and Kerst was already pressing ahead with new research for the company when the article was accepted for publication. There was no time to be lost. Nuclear science was on the rise. With optimal management, the electrons in the little apparatus achieved a radiation level equivalent to about one gram of radium. With the price per gram of radium equivalent to about 2.5 million dollars in today's values, it is hardly surprising that Kerst's machine excited attention. Its possible use in medicine was seen immediately.

The way the news about Kerst's betatron reached Rolf is a story in itself. It happened at a meeting of the Physics Society at the University of Oslo in October 1941. It was a rather unlikely sequence of events that would not have happened if the German censorship and postal restrictions had been fully efficient. The war had stopped access to new technical and scientific literature in the libraries. All postal connections between Norway and the Allies had been cut off, and when the USA entered the war postage from there was cut off too. Nevertheless, a remarkable breach of these restrictions occurred when a copy of the current issue of Physical Review came in the ordinary post to Roald Tangen at the Norwegian Technical College in Trondheim in autumn 1941, a few days before he was due to deliver a lecture on particle accelerators in Oslo. During his lecture he reported the news of the American who had managed to build a betatron that worked. He had 
also studied the list of references, and he informed the meeting that it was the work of a Dr. Widerøe that had laid the groundwork for the invention.

Tangen has also told the story himself and explained that his reaction when he read the article was that he 'didn't know any Rolf Widerøe, but that judging from the name this must be a Norwegian.' So a key person in experimental physics at the Norwegian Technical College in Trondheim didn't know about Rolf's contribution until he learned about it from an American. But Rolf himself was in the room, and after the lecture he introduced himself. Thus they met for the first time: Tangen, who worked with Van de Graaff generators and later became a professor both in Trondheim and in Oslo; and Rolf, who made an international career with his betatrons. He has also told of the second time they met at the same place, many years later when Rolf was delivering the lecture. The interesting thing about this account is what Tangen doesn't mention:

It would be 42 years before we met again. In the same auditorium where I had spoken about Kerst's betatron, 80-plus year old Widerøe was talking about his academic career, at the invitation of the University of Oslo. In my vote of thanks, I referred to what had happened in the same place in $1941 .{ }^{52}$

Tangen skipped over the fact that he had had dealings with Rolf in the meantime and had almost held his fate in his hands. He could hardly have done otherwise as he stood at the lectern with Rolf in the room.

\section{Hot on the Trail}

When Rolf got hold of the journal and was able to read it for himself, he saw with his own eyes that what the Americans had written could be understood as a natural continuation of his own ideas, and also of the ideas of the later Nobel Prize winner, Ernest Walton, which were developed independently and almost at the same time. The news from America stimulated Rolf to action. This was the field he should work in. The calculations should be done again. That Kerst had found this solution was one of the most useful things that could happen. Mountains are there to be climbed. Stumbling is an opportunity to learn to get up again. While still working at NEBB he also worked for several months on a new scientific paper. He then sent a long manuscript to the same German journal that had published his doctoral thesis and also subsequent articles. This time he wrote about how it would be possible to make betatrons with higher energy than he had written 
about in his thesis and even higher than in Kerst's betatron. He submitted the article on 15th September 1942 and it was published the following spring. These dates were not important at the time but they would prove to be important later.

He didn't stop there. He wrote a further article a few months later about how the energy could be raised a further notch. He wrote about how to construct a betatron that would produce radiation with energy of not two million like Kerst's, but two hundred million electron-volts. A little more high-flown than the first article, certainly. Submitted to the same journal in Berlin. For one reason or another it was not published. Perhaps it didn't arrive. Perhaps it was stopped by a German censor. In wartime, everything is possible.

Rolf was in mid-life now. He had just passed forty. Father of small children. Full-time employee at NEBB, articles to write, meetings to go to, documents to read in the evening. Trying to keep himself updated about the physicists in Bergen who were eagerly trying to establish a nuclear laboratory and who also, oddly enough, came to hear about Kerst's betatron in an unusual way, but only towards the end of the war. Odd Dahl, who had once worked at the Carnegie Institute in Washington, wrote about this in his autobiography, in the chapter entitled As an 'atom spy' in the USA:

I had received a film roll from the USA via London. One winter night in 1945 I noticed somebody walking up the dead end street to our house in the suburbs of Bergen. It turned out to be the leader of the home front in Bergen. He gave me the film roll with the information that it had been handed over to him from London. Not much more was said.

It was my old friends and colleagues Tuve and Hafstad who had initiated this. They were engaged in electronic research of great importance for the conduct of the war, but the film was not about that. It described in text and diagrams the details of a new type of electron accelerator that had been built by Dr. Donald Kerst, who was unknown to me. The accelerator was known as a betatron, and Kerst and a colleague had built a functioning installation in 1940. This would undoubtedly play an important part in future atomic research, so Tuve and Hafstad had quite rightly thought that it would be of interest to me. ${ }^{53}$

Dahl eventually realised that Rolf had been in the picture, and even though Dahl had good contacts in the USA he credited Rolf in his memoirs. By that time the pair of them had both met and worked together. He had developed great respect for Rolf, and he gives honour where honour is due: 
Kerst did indeed build the first betatron, but twelve years before he got it to work the Norwegian Rolf Widerøe had formulated the principles for such a machine.

\section{Following the Trail}

These were dramatic times. Research groups were competing to be ahead. In Norway certainly, but mainly between different researchers in the USA and between the USA and other western countries. Competing in atom-splitting, accelerator technology, use of atomic power, new machines. In Europe the Second World War was coming to a climax with the Battle of Stalingrad which was a catastrophe for the German war machine. Hitler was becoming more and more desperate and was looking for something to convince the world — and his own people — that Germany would win the war.

There was now widespread speculation among the allies that the Germans were designing an atom bomb. Most people thought this was just propaganda. The German public didn't know what to believe. Anything might happen. The research became part of the war effort. The Americans started their Manhattan Project to get ahead of the Germans. In Germany, Hitler shuffled the senior people in political control of research programmes. New talent was brought from the inner circles into the atom project, with instructions from Göring to get a move on. See to it that better weapons are produced, and fast. Wonder-weapons. The Luftwaffe racked up its own research, used its contacts, hunted through the scientific and technical community for able people. Anything that could be considered important for the war effort was prioritised.

1942-1943 was a hard wartime winter in Oslo. But Rolf seemed to be holding things together. A Nazi father-in-law, a brother captured by the Germans. A full-time job plus his own research in which he became more and more absorbed. Adversity had never stopped him. He was on the trail now. He had rediscovered the research interest he had worked on in Karlsruhe. Theodor and Carla's eldest son was really beginning to make his mark.

\section{Surely not ...?}

Then the Widerøes' world seemed to collapse. For the elderly parents in their house at Vinderen, domestic calm was shattered. Rolf had taken a job in Germany! On a German research project, in Hamburg of all places! The 
city where Viggo was in prison. Rolf would commute by air, in a German plane. Norway was still at war with the Germans. Could things be any worse in August 1943?

The Gestapo were ravaging the country. 1100 Norwegian officials were arrested in their houses. 1200 Oslo students were captured, and half of them sent to Germany. 500 politicians were interned in the prison at Grini. Viggo had also been there, as one of the first-prisoner number 352-before he was sent to Germany. It was good that they didn't yet know that prisoner number 8197 had been transferred on 29th July from Grini to the concentration camp at Nazweiler. After the war he would become Rolf's brother-inlaw when he married Ragnhild's sister. And as Rolf's son Arild later said, 'If Uncle Arild had not died in the plane crash he would certainly have worked with the resistance and been caught by the Germans. I'm sure of it.'

Rolf's wife stayed on in the house in Røa in the Oslo suburbs, with three young children aged seven, five and two. Coping on her own with daily life, birthdays, ration cards, blackout curtains, neighbours, gossip and rumours. Not made easier by her father being a Nazi. Fortunately she was tough and knew her own mind.

The comfortable parental home is creaking at the joints. The ground is giving way, the world collapsing. Then everything is calm again. A father aged 75 and a mother aged almost 70 slowly manage to hold the family together. Christmas must be celebrated, Sunday lunches prepared and grandchildren cared for. One son has died, another is in a German prison. And now this business. Surely not... ? Rolf... ?

Then comes the news that Rolf has visited Viggo in prison. One of them working for the German authorities, the other arrested by the German authorities. Two brothers at the same place but each in his own world. The scene is so absurd that it will take years to see it in perspective and comprehend what has happened.

\section{Notes}

1. Else Widerøe and Elisabet Juel started Contact Service AS.

2. Else Widerøe died in August 2012, almost 99 years old, after this chapter was written.

3. Interview during preparation of the book.

4. Slektshistorie over ('Family history of') Kane - Aspen - Widerøe, written by Ivar Andreas Widerøe and published in Trondheim in 1981. 
5. Ole Studevold Hansen: Opptegnelser fra Tydalen, annex til Selbu. Kjell Haarstad, Per O. Rød: Selbu I fortid og nutid.

6. Wikipedia: Aftenposten 15 June 1997.

7. Thanks to two young Norwegians, physicist and scientific historian Finn Aaserud and physicist Jan Sigurd Vaagen, who had heard about his contribution, an interview was arranged with Rolf Widerøe, then aged 81, during his annual summer holiday in Norway. The interview took place in Oslo on 12th July 1983 at what is now the Nordic Institute for Studies of Research, Innovation and Education, and lasted almost a whole day. Two other physicists took part in the interview along with Aaserud and Vaagen, and the whole interview was recorded.

8. Some Memories and Dreams from the Childhood of Particle Accelerators, lecture dated 3rd December 1982. The meeting was at Geilo on 12th January 1983.

9. Aftenposten, 17th July 1971.

10. The interview with the physicists in 1983.

11. Pedro Waloschek: Als die Teilchen laufen lernten. Leben und Werk des Großvaters der modernen Teilchenbeschleuniger - Rolf Wideröe. Redigiert und zusammengestellt von Pedro Waloschek. In English translation: The Infancy of Particle Accelerators. Life and Work of Rolf Widerøe. Compiled and edited by Pedro Waloschek, Vieweg, 1993: Later referred to as 'The biography'.

12. The biography.

13. The biography.

14. The interview with the physicists in 1983.

15. Dr. Eugen Flegler.

16. Professor Karman.

17. Notgemeinschaft der deutschenWissenschaft. The organisation was then only four or five years old. It is now called the Deutsche Forschungs-Gemeinschaft or DFG ('German Research Foundation').

18. The biography.

19. 'In 1924, Gustav Ising had suggested a principle of multiple acceleration, or repeated acceleration, of charged particles in a straight line. Widerøe brought Ising's idea into reality by establishing the principle of multiple acceleration using alternating current. Then he constructed the world's first linear accelerator, based on this principle, and showed that it worked in practice: $\mathrm{He}$ accelerated $\mathrm{Ca}$ and $\mathrm{Na}$ ions to $50 \mathrm{keV}$ in two successive steps, each of $25 \mathrm{keV}$, in a high frequency voltage field. The principle of alternating current based multiple acceleration - first achieved by Widerøe - was the basis for the amazing development of both linear and circular accelerators that has continued throughout the twentieth century. A copy of Widerøe's accelerator now stands in the 'minimuseum' in the reception area of The Norwegian Radium Hospital.' (Tor Brustad in discussion during the preparation of the book).

20. The Dr. Paul Meyer Laboratory. 
21. J. Biermann in AEG and Reinhold Rüdenberg in Siemens.

22. Otto Meyer.

23. The biography.

24. Gregory Breit, Merle Tuve and Lawrence Hafstad.

25. Kaiser, H. F. (U.S. Naval Research Lab., Washington, D.C.): European Electron Induction Accelerators, in J. of Applied Phys. 18, 1-17 (1947).

26. Per F. Dahl: Rolf Widerøe: Progenitor of Particle Accelerators, Superconducting Super Collider Laboratory, Dallas, Texas, March 1992.

27. The biography.

28. Nordmenn I fangenskap ('Norwegians in Prison') 1940-1945. An alphabetical register with an introduction by Kristian Ottosen.

29. Helge Skappel and Viggo Widerøe: Pionertid ('Pioneering Time'), Oslo 1945.

30. The three were Halvor Bjørneby, Helge Skappel and Leiv Brun.

31. He wrote Sunday 13th March, but the 13th was a Monday. So the date must be 12th March, as the display took place on a Sunday.

32. Turi Widerøe presented an excerpt of his father's description in a series of articles in the airline's magazine, Perspektiv, in connection with the company's 75 year jubilee in 2009. This text is from the February 2007 issue.

33. No. 8, 15th March 1933: Relébeskyttelse i krafffordelingsnett ('Relay Protection in the Power Distribution Network').

34. No. 14, 15th May 1934: De forste kotslutningsfors $\emptyset$ k med norske distansereléer ('The first use of Norwegian distance relays to detect short-circuits').

35. Helge Skappel and Viggo Widerøe: Pionertid ('Pioneering Time'), Oslo 1945.

36. Erik Engnæs, Ditlef Smith, Helge Skappel and Leiv Brun were also members of the company. The latter two, together with Halvor Bjørneby and the brothers Viggo and Arild were the day-to-day driving force.

37. One source says that he met her at Svas danseskole in autumn 1933, another that they met at Miss Fearnley's Dance School in February 1934.

38. That is how Viggo described it in the airline's 50-year jubilee book the year before he died.

39. Per Arne Watle in: P.A. Watle: Oppdrift $i$ motvind ('Soaring Against the Wind'), Abstract, 2004.

40. Helge Skappel and Viggo Widerøe: Pionertid ('Pioneering Time'), Oslo 1945.

41. Turi Widerøe: Is, fly og skip. Oppdagelse og kartlegning med fly i Øst-Antarktis 1929-1939. ('Ice, Planes and Ships. Exploration and Map-making by plane in East Antarctica 1929-1939). Masters degree dissertation in history, History Department, Humanities and Social Studies Faculty, Tromsø University, 2006.

42. The biography. 
43. Helge Skappel and Viggo Widerøe: Pionertid ('Pioneering Time'), Oslo 1945.

44. The biography.

45. Eugen Flegler, one of the assistants of Rolf's supervisor, Rogowsky.

46. The biography.

47. The biography.

48. Lawrence and his Laboratory. A Historian's View of the Lawrence Years. Published in 1981, in honour of Berkeley Laboratory's 50th anniversary. Chapter 3: 'Deflecting Physics for War.' Nuel Pharr Davis: Lawrence and Oppenheimer, 1968.

49. He says 5,000 kroner in the biography that was written in 1993 , but he doesn't specify whether the payment was 5,000 kroner in 1938 or the equivalent of 5,000 kroner at 1993 values.

50. The quotations are from the biography.

51. Otto Hahn and Fritz Strassman.

52. He wrote several articles on this topic, including 'Thoughts on the Energy Situation, Atomenergie (ATK) Bd 31 (1978) Lfg. 2.

53. The biography.

54. Trollmann og rundbrenner ('Wizard and Maverick'), Gyldendal 1981.

Open Access This chapter is licensed under the terms of the Creative Commons Attribution-NonCommercial-NoDerivatives 4.0 International License (http:// creativecommons.org/licenses/by-nc-nd/4.0/), which permits any noncommercial use, sharing, distribution and reproduction in any medium or format, as long as you give appropriate credit to the original author(s) and the source, provide a link to the Creative Commons license and indicate if you modified the licensed material. You do not have permission under this license to share adapted material derived from this chapter or parts of it.

The images or other third party material in this chapter are included in the chapter's Creative Commons license, unless indicated otherwise in a credit line to the material. If material is not included in the chapter's Creative Commons license and your intended use is not permitted by statutory regulation or exceeds the permitted use, you will need to obtain permission directly from the copyright holder.

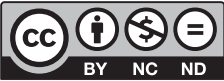

